\title{
Stemninger og Tilstande i Haderslev under Verdenskrigen.
}

\author{
Ved H. V. Clausen.
}

\begin{abstract}
I "Sønderjydske Aarbøger" for 19:9 meddeltes Oberst Detlef Nielsens Erindringer fra 1864. Hans Enke (1844-1924) blev anden Gang gift med Oberstlieutenant Røgind; under sin lange Enkestand efter ham tilbragte hun Ferierne hos sin Broder, Grosserer Julius Nielsen paa Damager. Her overraskedes hun af Verdenskrigen og valgte at blive hos sin Broder og hans Familie, for - skønt hun havde en Lejlighed i København, der tilsidst blev hende anfægtet - at være til Støtte. Hun har nojagtig fra Dag til Dag under hele Krigen nedskrevet sit private Arbejde, sine Glader og Sorger. Af alt detto meddeles her intet uden for saa vidt det tjæener til Oplysning om hendes Karakter eller Sympatier, men ved Siden deraf indeholder disse Dagbøger Stof, der forekommer en at vare af mere almindelig Interesse, givende - som allerede overskriften siger - Stemninger og Tilstande i Haderslev gennem hele Ulykkestiden, selvfølgelig subjektive, som Dagbogsskriversken var anlagt, men dog praget af den almindelige danske Opfattelse af Begivenhederne. Mest er det sig selv, hun rober, men af og til marker man ogsaa, hvad dels den danske Befolkning $i$ sin Helhed, dels de nordslesvigske danske Politikere som H. P. Hanssen og Julius Nielsen har skønnet, følt og haabet.

Til Forstaaelsen af, hvem de væsenligste Personer er, som omtales i Dagbogen, tjæner følgende: Julius Nielsen selv, hans Hustru Marie, fodt Roose, og hans fire Døtre: Thora, gift med Ritmester van Deurs, Cathrine, gift med Magister H. V. Clausen, bægge Døtre boende i København, Elisabeth, ugift, og Rose, dengang forlovet nu gift med Grosserer Paul Christiansen, Damager. Tante Christiane er Enke efter Grosserer Jørgen Roose i Haderslev, hendes Dotre er Fru Marie [Missen] Schmidt, dengang i Danzig, og Helga Ronse, nu Plejemoder ved Almindeligt Hospital i København. Fndvidere Rigsdagsmand H. P. Hanssen og hans to Dotre, Marie, gift med Direktor Sophus Thomsen, dengang Prokurist i Julius Nielsens Forretning paa Vojens, og Ingeborg, gift med daværende Redaktør ved "Hejmdal«, nu Amtmand i Aabenraa, Kresten Refslund Thomsen. Om andre Personer findes kortfattede Oplysninger indenfor de skarpe Klammer.
\end{abstract}

\section{4.}

Fredag 31. Juli. Tyskland mobiliserer. "Modersmatlet«s Kontor lukket. Ingen danske Blade udkommer mere. I.ebeck, Sarup forte til lhaadhuset. [Nic.] Svendsen undgik Arresten, da han var taget til Visby, men han eftersøges. Redaktør Mathiesen afhentet fra sit Hjem og transporteret gaaende gennem Byen. Man er indigneret ovrr ren Brutalitet. Rnse, Paul og Gladys [engelsk Dame i Besøg paa Damager] var tagne ud i Bil, men blev standset 
og visiteret ved Sønderbro, hvor der er anbragt en Bom nu. Hrad frygter man mon?

1. A u g. Tyskland har tilstillet Rusland sit Ultimatum, og vil Krigen blive erklæret, hvis ikke Rusland inden 24 Timer ophører med Mobilisering. Her er alt Uro. Thora ved ikke, om hun skal rejse. I Aabenraa H. P. Hanssen og flere arresteret.

2. A u g. Krigen erklieret af Tyskland. Inclkaldelser. Sorg overalt, men naturligvis siger de tyske Blade, at Krigen er retfærdig, og at den er blevet dem paatvungen. Dr. Thomsen fra Skærbæk [nu Amtslage i Tonder] her i Bil for at konferere med Fader. Han fortalte, at gamle Peter Skau var arresteret. Ligeledes Falle Liliholdt [Gaardejer paa Løjt] og Simonsen, Flovt. Vi er bange for Fader. IIavde projekteret Køretur til Sølyst, men har opgivet det. Vi synes, det er bedst. at vare samlede.

3. A u g. Gladys rejst i Dag. Vi er glade derved, under disse urolige Forhold er det dog bedst at være sig selv. Brev afsendt i Dag med Frk. Kall til Sxby. Det er den sidste Dag, der gaar regelmæssigt Tog. Thora ventede Telegram fra sin Mand; det kom for sent, og hun ser nu Tiden an. Vore Heste er tilsagt at møde Onsdag, de vil muligvis blive taget til Krigstjæneste.

I Dag til Sølyst, vist for sidste Gang. Alt øde og tomt, hvor vi kom forbi. Alle Mænd borte, ligeledes paa Sølyst. Talte med Bramsensgaard, hvis Søn og Karl var indkaldte; han sagde, der var ingen Udsigt til at faa Hasten bjærget, var meget nedtrykt; dertil kommer nu den evindelige Regn. Kornet ligger og raadner. Vi blev visiterede $i$ Byen, baade ved Ud- og Hjemkørslen, maatte staa ud af Vognen. Fader alligevel en hel Del urolig, har lange Konferencer med Hübbe [Direktør i Haderslev Bank] og med Thomsen [Julius Nielsens Prokurist]. Situationen alvorlig. Hvor det or drøjt intet at vide om Stillingen og Stemningen $i$ København.

4. A ug. Tyskland har kastet sig ind i Rusland. Frankrig mobiliserer, men vi ved jo intet rigtigt, da vi kun har tyske Blade: Grenzpost, Hamburger Nachrichten og Hamburger Korrespondent. En Masse Mejerifolk kommer her for at tale med Fader. De er alle meget bekymrede.

5. A u g. Englands Krigserklæring kommer som en Bombe; Krigen ogsaa uundgaaelig med Frankrig. Her holdes Bet- und Busstag efter krjserlig Anordning; hvilken Komedie. Det lader til, at de unge tyske er begejstrede, de drager gennem Byen under Afsyngelse af "Die Wacht am Rhein" eller "Deutschland über alles", og udenfor Landraaden har de endogsaa istemmet "SchleswigHolstein meerumschlungen". Der kom Brev fra Cathrine idag, men det siger intet; de var endnu i Sæby, da Brevet var skrevet. En Militærflyver forlystede sig i Dag over vore Hoveder. I Dag er Helle Roose kommet fra København, hun havde "Nationaltidende" med, og den blev slugt med Begærlighed; man ser, at der er stærk 
Uro og Gæring i København, men hvad skal der blive af vort lille Land og vor dejlige By. Enten vil Englænderne eller Tyskerne sætte sig fast der, og saa vil jo Kampen staa der. Man gruer ved Tanken. Nu er Øjeblikket virkelig kommet, det som saa mange alvorlige Mænd har forudset. Jeg vilde onske at være i min Rede, jeg synes ligesom det er Forræderi ikke at dele de onde Kaar med mine Landsmænd. Man taler om Indkvartering her i Dag. En Masse Arrestationer i Sonderborg, Tønder og Flensborg.

6. Aug. I Dag Kl. 7 Morgen fik Thora Telegram fra sin Mand, hvori han beder hende forblive her. Er det af Frygt for Bombardement paa København; man ved jo intet, og vor Neutralitetserklæring vil lige saa lidt blive respekteret som Luxemburgs og Belgiens; det har Bethmann-Hollweg tydelig nok sagt i sin Erklæring. Denne Uvished er forfærdelig.

7. A ug. I Dag Brev fra van Deurs og fina Cathrine, men de siger intet, er gamle bægge. Mit Brev har de ikke faaet. Afsendt Kort, skrevet paa Tysk, i Dag. Vi kan kun spadsere til Bøghoved nu. Der staar Vagt, der viser en tilbage. Skinner og Broer bevogtes. Her er ligefrem Panik for Spioner. Man har opslaaet alle Vegne Advarsel for at fortælle noget og Opfordring til at melde hvert mistænkeligt udseende Individ.

8. Aug. Bethmann-Hollweg sagde i Rigsdagen: "Wer so bedroht ist wie wir um sein höchstes Gut, der darf nur daran denken, wie er sich durchhaut«, og hele Rigsdagen har tiljublet ham Bifald. - I Dag passerede en meget kedelig Historie, som desværre kan faa vidtrækkende Følger; vi er alle urolige og paa samme Tid forbitrede. Missen og Helle kom med deres Ketsjere i Formiddags for at spille Tennis. Ingen havde rigtig Lyst. Rose og Lisbeth havde noget at bestille. Til sidst gik Thora ud med dem og de begyndte. Senere kom Lise og de blev ivrige. Rose var der som Tilskuer. Der blev rangeret $T o g$ i det uendelige og tilsidst, henved 12, holdt der en Del Vogne med Heste og Soldater paa Skinnerne ligeoverfor Tennispladsen, medens Resten af Toget endnu rangerede. Soldaterne morede sig med at se paa de spillende, der kom ogsaa Drenge og andre og alt gik fredeligt, indtil to Herrer kom, som hurtigt forsvandt efter ogsaa at have iagttaget de spillende. (Det kom de i Tanker om bagefter). Saa vilde de lige til at holde op, saa ser de pludselig Strackerjan [Redaktor af Grenzpost] og en anden Herre komme med hurtige Skridt, Strackerjan oppustet som en Kalkunhane, nærme sig Gitret og sige: "Pfui, schämen Sie sich" og en hel Del mere. Lise siger ;il de andre om at vare rolige og gaar hen til ham og siger: "Synes De, det er gentlemanlike at skælde Damer ud, og det paa deres private Grund". I det samme Øjeblik er der en gammel graaskægget Mand [Gerichtsvollzieher Otto], der stikker en Spadserestok under Staaltraadsgærdet og puffer Lise i Brystet. Saa vendte Lise sig om, da hele Hoben, der efterhaanden havde 
samlet sig, truede. Strackerjan greb den gamle Fyr i Armen og sagde: "Ruhig, keine Gewalttat". Thora og Helle blev saa forbitrede over denne Opforsel, at de demonstrativt igen begyndte at spille, skønt Lise opfordrede dem til at lade være. Rose var imidlertid løbet ind til Fader, der var stixkt forkølet og laa paa Sofaen, og havde fortalt ham om Optrinet derude. Han sagde straks: "Sig til dem at holde op". Imidlertid havde der samlet sig flere og flere, man mener hundrede Mennesker, og Strackerjan blev saa forbitret, at han kastede sin Stok ind paa Tennispladsen. Den kom ikke derind efter det første Kast, men faldt i Hovedet paa ham selv. Endelig tredje Gang fik han den ind. Den faldt lige ved Helle, og han raabte: "Pfui, wie schamlos", "und das sind keine Damen", og i allerhøjeste Bersærkergang avancerede han hen til Iøren til Tennispladsen, hvor de andre stod. Lise gik ham et Par Skridt i Møde og opfordrede ham til at holde op med sin Skælden: Det var paa privat Grund, han opholdt sig. Han stampede med Fodderne og raabte, ude af sig selv: "Ich spreche nicht Dänisch, das sind keine Damen, die sich so aufführen, wenn es Leben und Tod gilt.» Tilsidst raabte han: "Nun will ich meine Soldaten Adieu sagen«. Saa sagde Lise paa Tysk: "Daran thun Sie auch besser". Hele Mrengden hujede og raabte, saa kom Toget med hele Regimentet, der skulde rejse den Dag. Børnene kom ind, og vi blev jo alle meget altererede; Fader, som var syg, i Særdeleshed. Stókken blev desværre hentet af en Dreng paa Pladsen. I Krigens Hede tænkte ingen paa den. Tænk ellers, hvilket Vaaben mod Strackerjan. Ingen af de tennisspillende vidste noget om, at Soldaterne, hvorimellem der var saa mange af vore egne, skulde rejse den Dag; de kunde intet se fra Pladsen, da Toget var frakoblet ved Overgangen og de Vogne med Soldaterne forst begyndte ved Bryggeriet; havde troet, det var kun nogle Vogne med Heste og Hestepassere, havde nok syntes, der var forfærdelig mange nysgerrige, men saa været saa ivrige og optagne af Spillet, at de ikke bekymrede dem om mere. Det var en bevæget Dag. Paul kom herud, havde været paa Banegaarden for at sige Farvel til flere Venner og Bekendte, havde set saa megen Sorg og Taarer, at han jo ogsaa var oprørt over, at de havde spillet Tennis, havde hørt, det hele i Byen gik som en Løbeild, men da han saa fik det hele forklaret, saa han jo med vore Øjne og fandt Strackerjans Opførsel mildest talt skandaløs. Men vis paa, at der kom noget ud af den Historie, var vi jo alle, og at det nærmest vilde gaa ud over de danske Undersaatter, det var vi klar over. Thora og jeg sov lidet og spiste lidet. Saa havde jeg jo ogsaa en stor Skræk for Fader og Lise og Rose, særlig de to sidste, at de skulde komme i Fongsel, og naar man saa [selv] var udvist, hørte og vidste man intet. Det var en frygtelig Dag. Ogsaa den Tanke, at alle, baade tyske og danske, vilde dømme Børnene strængt.

9. Aug. Vi er alle meget ængstelige og alvorlige. Kl. 4 
Eftermiddag kom Politibetjent Harder for at tale med Lise. Hun maatte sige sin Alder, og hvem der havde varet paa Pladsen den Dag; ogsaa Thoras Alder og saa videre og alle mulige Oplysninger. Saa kom Turen til Rose, saa til dem, der opholdt sig i Huset. Efter det ventede vi alle enten Fængslings- eller Udvisningsordre for os for at straffe Fader paa den Maade. Fader var syg, ellers burde han allerede Lørdag være gaaet til Landraaden og beklaget sig over den Medfart, hans Damer havde faaet.

10. A ug. Paul været her og Missen og Helle, de tænker at tage afsted. Stemningon i Byen mod de tennisspillende umaadelig forbitret, ogsaa danske er oprørte, og hvad der ærgrer mig, at Venner af Huset kun har hørt Fordømmelsen ude uden at vente, til de hører nærmere. Strackerjans Opførsel bliver lige forkastelig, det var ikke hans Skyld, at det blev ved den ene Sten, og at de ikke blev overfaldne af Hoben. Tante Roose været paa Borgmesterkontoret for at faa Pas. Stemningen helt forandret. Ingen Udvisning at frygte. Pas behøves ikke. Man gisner om, at Danmark vil alliere sig med Tyskland. Tror det ikke, vil ikke tro det. Grænsen aaben for Indførsel. Missen og Helle bliver, Thora vil rejse i Morgen, nu det lader til, Passagen er fri. Jeg veed ikke, snart onsker jeg at rejse med Thora, snart synes jeg, jeg ikke kan udholde at være borte fra mine kære her og være helt uden Efterretninger, her vil ogsaa blive svære Tider. Det er, ligesom vi er blevet roligere, da der ingen Arrestordre er kommet.

11. A ug. I Dag Kl. 9,20 rejste Thora. 12. A ug. Rose fortalte mig Pauls Henvendelse til Landraaden. Godt gjort, syntes jeg. Det er, som alt bliver lidt lysere om os, at dog ikke alle skal betragte Hændelsen som Taktløshed og Hjærteloshed.

13. A ug. Fader og Lise paa Fisketur; mens vi sad ved Kaffebordet, kom "das Nachspielı. Politibetjannt Harder med tre Skrivelser til Thora, Lise og Rose, hvori de var idømt Bøder for "grober Unfug"; til Fader ogsaa en Skrivelse med Bøde for ikke at have meldt Familien van Deurs, Fru Clausen og mig i rette Tid. I Aftes kom Tante Christiane og Missen og Helle, ogsaa de havde faaet Bøde. Fader vil naturligvis gøre Indsigelse.

15. A ug. Fru Mathiesen her i Middagsstunden. Meget nedtrykt, intet hørt fra sin [kræftsyge] Mand.

19. A ug. Fader hos Landraaden. Han raadede til under disse Forhold rolig at betale sin Bøde og intet at gore. Lise flyver i Flint.

20. A ug. H. P. Hanssen her. Havde den samme Opfattelse som Landraaden, under disse Forhold intet at gøre, illustrerede det med Eksempler fra sin Rejse fra Berlin nu, (havde brugt 32 Timer) og Eksempler fra Aabenraa. Han mente snart at kunne faa Fangerne her frigivne. Lise meget oprart. Missen og Helle, der var her 
i Aftes, det samme. Nu maa de altsaa smukt kysse Riset og betale Bøden for "grober Unfug".

23. A ug. Søndag. Været i Sølyst. Prædiken ved Stranden af Pastor Petersen [fra Starup]. Spadserede forbi og hørte til min store Forbavselse i Prædiken Begivenheden paa Tennispladsen; de unge Piger stempledes som manglende Følelse og havde udvist en Hjærtets Raahed. Tante Christiane var gaaet ud for at høre Prædikenen og havde placeret sig mellem Fiskerne og deres Familier, der var siddende $i$ en Rundkreds i Sandet. Hun kom op i en Fart, da hun opfattede, men tog saa senere Affære, talte længe indgaaende med Pastor Petersen, som fik hele Historien, og Resultatet blev, at han kom hen til os og gjorde en haade alvorlig og hjærtelig Undskyldning for sin Ubetænksomhed, var i det hele en sympatetisk Mand.

1. Sept. Tante Christiane var her og far meget oprørt over ct Brev, hun havde modtaget fra Pastor Petersen. Han fortryder øjensynlig sin Undskyldning og beskylder Tante Christiane for Usandhed, har faaet Referat af denne Otto.

2. Sept. Sedandagen. Stor Skandale hos Høppner i Gaar. Der var Danske, der ikke vilde rejse sig, da der blev udbragt Leve for Kejseren, og [Advokat] Dähnhardt, der er Kommandant i Byen, erklarede, de skulde arresteres, hvis de ikke gjorde det, osv. En blev smidl ud af Vinduet, og hele Norregade havde spor af Blod.

4. Sept. Nu maa der ikke telefoneres til Vojens undtagen paa Tysk: "Das ist Befehle. Det er forresten nydeligt $i$ en dansk Forretning. Tre Gaardmand fra Magstrup, Peter Fuglsang var den คne, or blevet arresterede og forte til Vojens til Forhør, var indesparrede $i$ et frygteligt Rum, medens de ventede paa Majoren, der dog løslod dem med en Advarsel. En havde sagt til Stationsforstanderen, at man ikke kunde tro de tyske Avisor, han troede mere paa de danske. Fn anden havde sagt til Gendarmen, at et bestemt Regiment var oprevet og odelagt. - Nu er atter Smørret stoppet og de maa aflasse Vognene. Det er en svar Tid i Forretningen [Julius Nielsens paa Vojens].

14. Sept. Franskmanden har kastet Fjenden tilbage foran Paris. Hurra. Bare, bare, man begynder at haabe. 23. Sept. Nu faar vi ikke mere danske Blade. "Forbudt", sagde Postbudet. 24. Sep t. II. P. Hanssen her med en Reichstagabgeordneter Dr. Breitscheid. De drak et Glas Vin sammen med os. Dr. Breitscheid en moget smuk, meget tiltalende, intelligent ung Mand, vi var alle indtagne i ham. 26. Se pt. Nu faar vi atter "Politiken«.

9. Okt. Sørgeligt Nyt. Antwerpen er faldet. Byen fester, flager. Der er Fakkeltog med Musik i Aften.

11. Okt. Pastor Prahl har i Dag holdt en Krigsprædiken, har hævet denne Bedrift at skyde en stakkels By sønder og sammen til noget enestaaende, og naturligvis har Gud fort og bragt til Sejr 
Guds udvalgte Folk, "Verdens Salt«. 29. $0 \mathrm{k}$ t. Ingen Petroleum at erholde nogen Steds. Far har sendt Bud efter Elektrikeren.

2. Novbr. I Gaar fik Lise sat igennem, at "Hændelsen" optages. 8. Novbr. Nu er altsaa "Sagen" begyndt, men straks med en Fadæse. Advokat Andersen har ikke sagt Børnene, at de skal mode personligt hos Forligsmanden. (Sadelmager Zierau). Fader sagde, det havde han aldrig gjort ved sine Processer, og de rettede dem derefter. Nu lader det til, at det er nødvendigt, og da det hele er kommet frem i sidste Øjeblik, er der nu Fare for, at det hele falder til Jorden og slet ikke kommer til Forhandling. Lise rasende. Nu vilde begge gaa til Advokaten i Morgen.

9. Novbr. Børnene i Byen i Dag for at faa fat i Andersen og holde ham til Ilden og finde paa en Maade, hvorpaa Sagen atter kan optages. Skammeligt ogsaa, at de har begyndt saa sent. Der er jo saa mange nødvendige Formaliteter og Fader viser ingen Interesse derfor. Jeg veed ikke, hvad der er i Vejen, om han er ængstelig.

10. Novbr. Skammeligt. Nu maa vi da oven i Købet betale Bøde, hver 1 Rmk., fordi de ikke mødte hos Forligskommissæren. Gendarmen var her og krævede den. Nu griner de naturligvis allesammen. Lise rasende. Nu mener Advokaten, at det maa være muligt at faa Sagen frem paa den Maade, at der indgives Klage til Statsadvokaten, som saa skal føre Sagen mod Strackerjan. Han har skrevet Klagen meget godt, synes jeg.

14. Novbr. Frk. Windfeld fortalte i Gaar, at der var mange unge Nordslesvigere (Danske), der havde meldt sig som frivillige. Hun saa meget pessimistisk paa det hele, fortalte om Stemningen paa Landet, nævnede Navne paa flere af dem, der havde meldt sig. Det maa være en Suggestion, man forstaar det ikke.

17. Novbr. Man kunde ikke faa det varmt i Stuerne, det er jo frygteligt, hvad skal det blive til, naar Vinteren rigtig begynder. Damerne sad med Overtøj paa hele Aftenen.

18. N o vbr. Bededag og Bodsdag. Ja, Tyskerne kan trænge til at gore Bod for al den Elendighed, de er Skyld i. 23 . Novbr. Nu maa man ikke tage til Vojens uden Pas. Alt er bleven skærpet. Gud ved, hvad de frygter for. "Grenzpost" stadig ophidsende imod Danmark. 24. Novbr. Brandes havde en udmærket Kronik. 27. Novbr. Der er kommet Efterretning om stor Sejr, Hindenhurg har vundet i Rusland. Hele Byen er i Begejstring. Klokkerne ringer og Børnene har fri fra Skole og Fokkeltog og Skraalen af Fædrelandssange. Fader mener, at meget er lavet, fordi Rigsdagen skal sammentræde og bevillige 20 Milliarder.

29. Novbr. Lise med Thomsen paa Jagt. Skal have Pas med Fotografi for at komme til Vojens. Gud ved, hvad de er bange for. Mange stakkels Nordslesvigere faldne. Det er en Lidelse at læse Navnene paa dem. 
1. De cbr. Kejseren har udnævnt Hindenburg til Æresfeltmarskal. Hindenburgs Svar uhyre karakteristisk, saa ægte tysk, nej, Kultur har det Folk ikke. Haderslev skal ogsaa være med i den almindelige Begejstringsrus. Nu bor vi ikke længere i "Alt Haderslebenerstrasse", nej, den er blevet omdabt til "Hindenburgstrasse«. Der gik et Cirkulære omkring i den Anledning for at samle Underskrifter, hvilke latterlige Barnestreger i denne alvorlige Tid. Udmærket Artikel af Brandes om det tyske Synspunkt. Hans Fremstilling er saa tydelig og klar og overbevisende, at den ikke behøver Kommentar. Jeg har klippet de tre Kroniker ud. Naar.Krigen er forbi, vil de have Levedygtighed. - Vilhelm Hansen, Hygum Mark, har skrevet hjem: "Hvis jeg falder, saa skriv ikke, at jeg er falden paa Slagmarken, men paa Slagtebænken. Som Køer bliver vi drevne frem, vore Køer hjemme har det langt bedre end vi. Naar vi ser en Roemark, kaster vi os over den, saa forsultne er vi."

3. De cbr. I Dag Brev fra Advokat Andersen med vedlagte Breve fra Statsadvokaten, Flensborg og Kiel, at de ikke kan tage Hensyn til Klagen, da den er indgivet for sent. Efter den og den $\S$ i Rigsretten skal Fristen regnes fra den Dag, Fornærmelsen blev tilføjet. Efter Andersens Opfattelse udlab Fristen forst Midnat mellem den 8. og 9. Novbr. Desuden, siger Statsadvokaten, er der ingen Grund til at optage Klagen.

16. Decbr. "Politiken" har været min Trøst altid, naar Sejrsefterretninger har gjort mig trist. Dens Resumé er klart, og man faar dog det Indtryk, at der er langt igen for Tyskland, og at Udsigterne ikke er saa lovende, som "Grenzpost" vil give det Ud. seende af.

17. De cbr. Det fortælles, at i Berlin og ogsaa somme Steder i Felten er den daglige Hilsen i Steden for God Dag og Farvel: "Gott strafe England". En Lieutenant fortæller i "Grenzpost", at hver Morgen, naar Kompagniet stiller, siger Kaptajnen de Ord, og Mandskabet svarer paa een Gang med høj Røst: "Er strafe es«. Det er kun Tyskere, der kan gøre den Slags Ting.

\section{5.}

2. J a n. I Dag har Fader modtaget efterfølgende Brev: An das kgl. Amtsgericht. Als Belastungszeuge geladen in der Privatklage der unverehelichten Elisabeth Nielsen der Sache nach - den Kaufmann Julius Nielsen vertreten durch den Rechtsanwalt Andersen gegen den Gerichtsvollzieher Otto, alle in Hadersleben, erkläre ich hierdurch infolge neuester Vorgänge auf dem Gebiete internationaler dänisch irridentistischer Politik, dass ich mein Zeugniss auch ohne gesetzliche Gründe verweigern werde. Ich kann es mit meiner Selbstachtung grundsetzlich nicht vereinigen, in dieser Krigszeit in einem politischen Prozesse gegen einen allgemein geachteten kaiser- 
treuen Kampfgenossen von $1870-71$ solchen Persönlichkeiten wie dem Kaufmann Julius Nielsen und dem Rechtsanwalt Andersen, welche in In- und Ausland den politischen Interessen unserer Kriegsfeinde bedauerlichen Vorschub geleistet und überhaupt eine sehr anfechtbare politische Moral namentlich auf dem Gebiete der politischen Eidestreue bekundet hatten, überhaupt Rede und Antwort zu stehen. Ich bin mir bewusst dabei zugleich in grössster Ehrerbietung gegen den hohen Gerichtshof und in grösster Ehrfurcht gegen den allerhöchsten Gerichts- und Kriegsherrn zu handeln.

Strackerjan.

Se Familien siddende om Kaffebordet med denne Epistel. Den eneste Losning er, at Manden er gal.

4. Jan. Hvor jeg egentlig skammer mig over mine Landsmænd; de har glemt alle Forurettelser, alt drukner i det materielle; tjæne Penge, det er Lasenet, og saa mange som muligt, ligemeget paa hvad Maade; og Regeringen lukker et Øje med al Udførsel; det var en sørgelig Stund, vi fik dette radikale Ministerium, dette uldne Regimente. Jeg vil ikke tale om Indførsel af Heste, den gik i sin Tid over alle Grænser, saa kom Forbud, men kun officielt, her kommer endnu hele Vaggoner med Heste, med Kreaturer. Jeg vil ikke tale om, hvad der fra Faaborg kommer hertil af Kolonialvarer, fra Assens. Nu faar vi ogsaa Gummi; Pølser og Islandsk Lammekød gaar som Fedt i Fustager, store Sendinger; i Vamdrup er etableret en Speditørforretning, der beskæftiger otte Personer paa Kontoret, alt for at faa Kontrabande over Grænsen. Er det fair mod England? Har de da alle glemt, hvorledes Preussen har behandlet Danmark, anfaldet det og mishandlet Sønderjyderne. Af Gullasch bliver her indført enorme Mængder, og Gud veed hvormeget af Korn eller Mel.

7. J a n. Efterretning idag, at to Tvillingbrødre Iversen, Sonner af en Hestehandler i Christiansfeld, er deserterede; de var hjemme med Orlov i Julen. Man siger, de er gaaede til Danmark, de skulde have været afsted til Fronten nu i disse Dage. De er danske. De Stakler, nu kan de aldrig komme her mere. Man undres kun over, at ikke flere deserterer. 15. J a n. Der begynder at komme virkelig Frygt til Orde for Brød- og Kartoffelmangel. 16. Ja n. Man flager i Byen.

20. Jan. Den unge Mnller [Son af senere Borgmester Thorvald Moller] var paa Visit. Ilan har 4 Dages Orlov, inden han skal til Fronten; han var blevet magrere, højere, mere mandig; han saa godt ud i Garderuniform. Han har haft en skrækkelig Tid i Lejren ved Döberitz, daarlig Kost, ikke mæt, og liggende paa Gulvet paa en Madras med et Tæppe, Vandet sivende ned, Øvelser fra tidlig Morgen til sen Aften. Alt skal jo indøves $i$ en Fart, at de kan komme afsted til Fronten. Han fortalte slemme Ting om Behandlingen af Fangerne i Lejren ved Döberitz; særlig Englænderne blev usselt behandlet. Han var i det hele taget ikke glad ved Fremtiden. Sollaterne vil hellere til Rusland 
end Flandern: Englanderne skyder for godt. Han havde kun truffet cen, ller gærne vilde afsted, alle de andre var triste. I Berlin, fortalte han, er dog endnu Begejstringen levende; naar Tropperne drager afsted, bærer de unge Piger Geværerne og smykker dem med Blomster. Men der var allerede megen Nød, de fattige tiggede af Soldateme og stod opstillede og ventede.

21. Jan. Her er Afslutningen paa Elisabeths Sagsanlæggelse mod Hr. Otto, stod i Aften i Grenzpost, saaledes naturligvis ogsaa perfid, men der or jo intet at gore i disse Tider. Nogen videre Oprejsning giver det jo ikke:

Schöfengericht. Bei der Abreise unseres Bataillons nach dem Kriegsschauplatz ist es bekanntlich zu einer peinlichen Scene gekommen, die dadurch hervorgerufen wurde, dass auf dem Tennisplatzo des Herrn Jul. Nielsen auf Damacker einige Damen Tennis spielten, was allgemein als eine Herausforderung empfunden wurde. Dic Erregung war infolge dessen gross und allgemein. Gerichtsvollzioluer a. D. Otto wurde über das Verhalten der Damen so prregt, dass er Fräulein Elisabeth Nielsen mit einem Stock berührte. Diese' strengte darauf eine Beleidigungsklage an, worauf $\mathrm{Hr}$. Otto Widerklage erhob, weil er sich durch das Gebaren der Damen in seinen vaterländischen Gefühlen verletzt fühlte. Diese Klagen kamen heute vor dem hiesigen Schöffengerichte zur Entscheidung, ohne dass es zu piner eigentlichen Verhandlung kam. Es kam auf Vorschlag des Gerichts folgender Vergleich zustande: Der Privatbeklagte erklist. er bedaure, dass er infolge seiner Frregung sich dazu habe hinreissen lassen die Privatklägerin mit seinem Stock zu berünren. IDie Privatklïgerin nimmt die Privatklage zurück. Der Privatheklagte nimmt die Wiederklage zurück.

23. J a n. Fru Boysen fortalte om en Arbejdsmand, der faar 30 Mk. om Maaneden (Invaliderente), Konen ogsaa svag, men nette danske Folk. Han sagde i en Samtale: "Ja, naar e Tyskere taber, saa er' et jo over med den Invaliderente, men det faar hjælp' sig". Det er saadanne Ord, der varmer.

24. J a n. En ussedvanlig flabet Artikel af Karl Larsen i "Politiken«: gill jeg engang kunde tale med ham. Horte en morsom Historie af Paul om Byens Indkøb af Fakler.

26. J a n. Visitter hver Dag, man kan marke, Boykotting er forbi, nu har vi ingen set siden i Sommer, og nu paa engang mai alle se til os.

27. Ja n. Der er kommet nye Forordninger, som træder i Kraft den 1. Febr., med Hensyn til Aflevering af det Mel, man har over 200 Pd., med Hensyn til Bagning. selv om det sker i Huset; man maa f. Eks. ikke bage Brod ullen Tilsætning af Rugmel; alt Kornet skal afleveres ud over en bestemt Mængde; dog, og det er det perfide, det kommer ikke i Betragtning, naar det er indført udenlandsk. 
Det vil med andre Ord sige, de begunstiger al Indsmugling af Korn, hvor det saa kommer fra.

29. Jan. Hver Dag Visitter, nu er der ingen Boykotting mere. Fru Schmidt fortalte fra sikker Kilde, at hver Soldat, der kan komme med Guldstykker, faar Orlov, det er skam Præmier at sætte. En Mand her fra Byen har skaffet 50 Rmk. i Guld og fik otte Dages Orlov. Paa den Maade faar de jo deres Guldbeholdning forøget. En engelsk eller russisk Undervandsbaad har været ved Rügen og beskudt og beskadiget tyske Skibe; hvorledes er den kommet derned, gennem Sundet eller Bælterne, man er meget oprort derover, og Grenzpost insinuerer, at Danmark halvt har været vidende, og at Danmark løber stor Fare.

1. Febr. En Masse modsigende Bestemmelser med Hensyn til Brødkornet og Anvendelsen af Melet. Bagerne er fortvivlede. Det bliver smaat med Guldet og Papirpengene, ja det bliver, hvis de taber, en ren Misère. Fader frygter dot vírste.

2. Febr. Vi faar stadig Takkekort fra de Soldater, vi har sendt til; i denne Uge kan vi sende eet Pd. i Pakker; derfor har jeg travlt med at emballere.

11. F e b r. Der er hartof felmangel. Der maa naturligvis have været fiffige Opkøbere, ellers forstaar jeg det ikke paa saa tidligt et Stadium. Paasch [død 1934 som Bankdirektor pata firasteen] i Forretningen er blevet taget, men har faaet nogen Respit. Man er bange for Thomsen; den Ansøgning, der er blevet indgivet fra Exportforretningen om at maatte beholde ham herhjemme, er afslaaet; Fader vil nu gaa til Landraaden. Al Kornforretning i Vojens er standset, og Smarforretningen er blevet saa vanskelig og med $\mathrm{Tab}$, at de er nedtrykte.

13. Febr. Som jeg havde ventet, stor almindelig Flagning i Byen, Sejrsstemning, Børnene fri fra Skole, Kirkeklokkerne ringede.

14. F e br. Man er her egentlig temmelig forbitret over Indforslen fra Danmark. Officielt er det og det forbudt udfort, men det sker alligevel, og her er der en Godstransport, som trodser al Beskrivelse. For det meste kommer det i plomberede Vogne og bliver først aabnet og efterset længere sydpaa; de er forsigtigere; men det siver ud alligevel.

17. Febr. Man flager, Jirkeklokkerne ringer, og Børnene har fri for Skole.

18. F e br. Hørte en Historic om en gammel 98-aarig Kone hos Bergs i Aastrup: Hun var glad, da Krigen udbrød, "thi saa kan jeg da begraves i dansk Jord«, og da Prosten besøgte hende, lod hun ham slet ikke komme til Orde og sagde tilsidst: "Ja, Hr. Pastor, de tyske de vil faa saa mange Klø, at de skal have 900 Aar for at forvinde det«. Den tyske Præst sagde ikke mere. 
22. Febr. Jørgen har faaet sin Indkaldelse, de er ulykkelige, de Stakler. Paasch og Paul indkaldte, der flages i Dag.

24. F e b r. Paul er taget, rejste med Toget Kl. 12 til Sønderborg, hans Broder ogsaa. Det var trist at se de unge Mennesker tage afsted. Stakkels Jørgen, Konen er meget trist, og han var det skam ogsaa. Hvor er Begejstringen nu. 25. F e br. Stor Forbitrelse allevegne. Deres Brød- og Mel- og Kartoffelhistorie har i Grunden været en Fjasko, Forvirring indtil nu allevegne. Man flager atter idag.

26. Febr. Hvorledes man som Karl Larsen kan beundre denne Brutalitet? Gud give, han kunde føle selv deres Fod paa sin Nakke og lide, hvad de undertrykte Folk har lidt, saa vilde han komme til at forstaa. Hernede bliver han aldrig mere anerkendt som god dansk Mand.

27. F e br. Man flager i Dag atter. Horte i Dag, at Soldaterne ved Grænsen er forbudt at tale dansk indbyrdes, og naar to Mand skal gaa Patrouille ved Gransen, bliver det altid een dansk og een tysk. Hvilken Tillid de viser de brave Nordslesvigere, som har kæmpet saa pligtopfyldende.

2 8. Febr. Kommet Svar fra [Advokat] Crespel i Flensborg, han beklager ikke at kunne føre Sagen imod Strackerjan, hans Helbred tillader ham ikke disse "Aufregungen", disse "Anfeindungen«, der vil følge den. Fader argier sig.

2. Marts. Prof. [Kristoffer] Nyrop et udmærket Svar til Karl Larsen paa hans Kritik af Bédicr's Uddrug af tyske Soldaters Dagbogsoptegnelser, holdt i en værdig Tone, hvori dog Forbitrelsen og Medfølelsen med Frankrig, Belgien klinger igennem og en vis Ringeagt for Karl Larsen.

5. Marts. Redaktør Svendsen fortalte i Dag, at der var kommet to stovte Landstormsmænd op paa Kontoret og bedt om at tale med "den bedst' Mand"; fort ind til sivendsen var deres Frinde at sætte net godt Stykkew ind i Modersmaalet; thi nu synes de da, det var for galt, det var blevet dem forbudt at snakke dansk paa Kasernen med hinanden, og det var meget besværligt for Svendsen at gore dem begribeligt, at han stod under Kommando og maatte gore kun, hvad de gav Ordre til. "Det er jo et' værd aa lev' i det her Land", sagde en af Mændene, for de gik.

7. Marts. Hver Dag kommer der store Vognladninger fra Danmark gennem Vojens; de er plomberede og gaar sydpaa. Man ymter om, at de af Korn har udført san meget, at de ingen Sædekorn har. Her tales Mand og Mand imellem meget derom, og de er enige $i$, at Nordslesvigerne efter Krigen vil opgive Danmark som Værn og Støtte. Store Ord og fedt Flæsk. 11. Marts. Man har flaget [osv.].

12. Marts. Paul kom hjem i Gaar Aftes og er blevet fri paa Grund af Øjnene. Stor Glæde. Kan bare ikke begribe, at det 
har kunnet lade sig gøre, da han har Korebrev som Chauffor, han har sandelig gjort det godt. Brødet bliver daarligere og daarligere, det er knap til at spise, og naar man saa hører, at $\mathbf{N}$. $N$. har bagt Brød af en Tønde Rug (22 Rmk.) og har regnet ud, at Smaafolk og anIre giver for hvert Brød saameget, at det samme Mel og Brød af een Tonde kommer op paa 64 Rmk., det er jo ublu, og saa er endda N. N.s Brød godt, mens det andet er slet. Det er den berømte Organisation. Det er sandelig at lade det gaa ud over de fattige, hvis vigtigste Næringsmiddel Brødet er.

13. M a ts. Vi fik ikke megen Musik, vi blev forstyrrede vel den urovækkende Meddelelse, at vi ingen Brød har kunnet faa, der var kommet Besked fra Raadhuset, at der intet maatte udleveres hertil, vi havde Mel og Korn nok. De andre er meget forfardede derover, da de san daarlig kunde undvære Rugbrød. Sikken Vilkaarlighed og sikken et Regimente. Det lader til, det. kniber for dem. 15. Marts. Hort at Thomsen, Aabenraa, er taget.

16. Marts. I Dag er Fader med Strackerjan for Forligskommissionen, som or en lillo solle Sadelmager Zierau. Strackerjan begyndte med at anstille sig, som om han slet ikke forstod, at der var noget fornærmende $i$ det Brev til Fader, han havde skrevet, og gjorde Fordring paa at laa at vide, hvori Fornærmelsen bestod Fader bad saa om at maatte se Brevet og sagde: "For det forste kan jeg gore Fordring paa at blive betitlet med IIr., dernæst er det en Fornærmolse: "Solche Persönlichkeiten“ osv., og tilsidst er det en grov Fornærmelse at tvivle om min Moral i Edsspergsmaalet. S. mente, at han ikke kunde se Fornærmelsen deri, og fandt, de burde komme "zur Einigkeit". Derpaa sagde Fader, han onskede ingen Enighed, nu vilde han lade Sagen gaa til Retten. Det greb $S$. straks og bad $Z$. føre det til Protokols, men Fader rettede sig og sagde, det mattr vare den anklagedes Sag at fremkomme med en Basis, hvorpaa der kunde forhandles, og ikke Klagerens. Derpad mente $S$., at der kun kunde forhandles, hvis Fader vilde melde sig ud af de danske Foreninger, ikke omgaas II. P. Hanssen og betragte Slesvigs og Holstens Afstaaclse til Tyskland som vendgültig“, og enclvidere maatte han soge at virke paa Befolkningen, at de ogsaa botragtede dot saaledes. Derpaa svarede Fader, at han ikke lod sig foreskrive Betingelser af S., og at Retten matte have sin Gang. - Det er en Sagfører i Altona, der nu vil fore Processen. Nu taar vi se. I Dag kom der et Kort til Fader fra et Sagforerfirma i Leipzig, og i det ene IIjorne var der et blat Stempel med de Ord: Gott strafe Fngland. Man skulde jo tro, de var alle gale, skruppende gale.

18. Marts. Brev fra Clemenceau til Brandes i "Politiken", udmærket, haaber blot, at min gamle Ridder sans peur et sans reproche vil svare aabent og mandigt, saa han kan blive paa den Fresplails, jeg har givet ham i alle de mange Aar. Man fortæller, at Tyskerne har købt flere store Landsteder paa Strandvejen ved 
København, hvor de har anbragt en Masse Betonunderlag til Bygninger, Pavilloner, Mure, som slet ikke behøvedes, i Lighed med, hvad de har gjort i Belgien længe før Krigens Udbrud. Den samme Mand fortalte ogsaa: Der var for et Aars Tid siden et Mode i Sydtyskland af Jærnbaneembedsmæind fra alle Lande, der var nogle danske imellem. Man forhandlede, man drøftede, og tilsidst kom jo "das Festessen", som var meget vellykket og livligt. Stemningen blev høj, den ene Dansker sad ved Siden af en preussisk Embedsmand, der efterhaanden blev "ein lieber Mann". I Samtalens Løb sagde Danskeren, at han var Stationsforstander i Slagelse. "Hvad", raabte Tyskeren, "meine Station", og saa forklarede han udforligt til stor Forbavselse for den pludselig helt nøgterne Stationsforstander, hvorledes hele Stationen i Slagelse var indrettet. Vognenes Anbringelse, Materiellet, og leende af fuld Hals sluttede han med at sige, at hver Station til København havde sin Stationsforstander ligesaavel instrueret som han, saa i Tilfælde af Krig kunde man sige: Es klappt. Hvad Danskeren sagde, vides ikke.

19. Marts. Brandes har svaret godt og mandigt og ham selv værdigt. Jeg er tilfreds. 20. Marts. Efterretning, at Thounsen skal mode til Session paa Mandag. Fader ikke glad. 22. Marts. En underlig urolig Dag, stadig ventende paa Efterretning fra Thomsen; han var en Del forknyt i Gaar og hans Kone ikke mindre. Gudskelov mellem 6 og 7 fik vi Underretning: Dauernd unbrauchbar. Hvor vi blev glade. Stakkels $P$. Bløcher blev taget og afgik samme Eftermiddag til Marienburg, der er ogsaa Thomsen fra Aabenraa. 25. Marts. Hanses Søster [Faderen, Peter Petersen, havde været Kusk paa Damager] fortalte en hel Del fra Skyttegravene i Frankrig; de faar nu ikke nok at spise, og de sukker alle efter Fred.

29. M a r ts. En Artikel af Clemenceau, der begynder: „Farvel, Brandes!“ Straks, da jeg havde læst den, syntes jeg trods dens ubeherskede Tone, at der dog muligvis var Sandhed $i$ de Beskylilninger, han rettede, og jeg frygtede atter for at miste Brandes. Det er naturligvis, fordi man er gammel og ikke har tilstrækkelig Dømmekraft, at man saaledes lader sig influere af det sidst skrevne. Men saa tog jeg og læste Brandes' Svar endnu engang, og saa var jeg paa det rene med, at Clemenceau har forløbet sig her lige overfor Brandes, og at hans Beskyldninger intet Grundlag har! men jeg undskylder ham, fordi han er Franskmand og lider for sit ulykkelige Land. Derfor kan han kun hevæge sig i Superlativer og fordrer det samme af andre. Jeg forstaar godt hans Folelser.

31. M a rts. Tyskernes Tropper begynder nu at skrive hjem, at de mangler Føde. Det vil ogsaa blive det, der vil bringe os Fred. Dyrtid og Sult herhjemme, og naar saa de stakkels Soldater klager, at de heller ikke bliver mætte, saa vil Uroen rigtig faa Fart og Opstandene komme, og saa maa vel den øverste Krigsherre sige stop. Jeg synes allerede, man mærker, de handler i Desperation. 
2. A pril. En hel Del russiske Fanger er internerede i den gamle forfaldne Gaard Stokkerhoved, og nysgerrige Mennesker valfartede derud og gik ligefrem ind i Gaarden for at glo paa dem. Grenzpost havde forrige Aften en Artikel, spækket med Gift og Galde, fordi medlidende Mennesker havde stukket lidt Cigaretter og Brod til de stakkels Fanger paa Banegaarden. Et Hib til Børnene var der ogsaa i Artiklen, naturligvis Hændelsen! den dør aldrig.

3. A pril. Skrevet tyske Kort til København. At vi nu ikke mere maa skrive dansk til vort Land! Og saa er der endda Folk, der venter sig noget af Tyskland, naar Krigen er forbi, som gamle Peter Skau. Ubegribeligt.

5. A pril. Kresten Thomsen, Aabenraa, er nu i en Lejr ved Kønigsberg; hans Fødder er meget angrebne. Han har været i Forhør og adspurgt, om han skrev hjem til Bladet. Det blev ham forbudt, ligeledes maatte han kun skrive tysk. Hvad han afsender og modtager, bliver læst. Han er naturligvis blevet angivet hernedefra. Det har de Tid til, saadanne smaalige Forfølgelser.

7. April. Lise ikke videre opbygget af at se den Godstrafik paa Vojens. Uafladeligt kommer det ene Godstog efter det andet, alle Vogne plomberede.

8. A pril. I Dag er atter blevet begravet tre stakkels russiske Fanger. Det er vel Hungertyfus, thi naar de kaster sig over raa Kartofler og Roer, maa Sulten være stor.

10. April. Direktor Schmidt her i Dag med Hilsener fra Cathrine og Victor; han var imidlertid meget forbavset over deres Forsvar for "Politiken", og i det hele over mange af de faldne Udtalelser. Frøken Windfeld fortalte om en Gaardmand fra Vestkanten, der havde ligget $i$ Slesvig og lige var hjemme paa Orlov, førend han skulde til Fronten; hun nævnede ogsaa Navnet. Han havde en Aften sammen med Kammerater siddet paa en Restauration, hvor en Journalist var kommet i Selskab med dem. Denne Journalist sagde: $\mathrm{Ja}, \mathbf{i}$ de allerfleste Tilfælde fan $\mathrm{r}$ Offentligheden intet at vide om, naar der er Tab og Nederlug. Hvormange Slag har vi ikke tabt, hvormange Skibe har vi mistet, som ingen udenfor Kredsen aner. noget om. Vi Journalister faar jo alligevel et lille Indblik i meget. Saa var der en af Soldaterne, der sagde: "Men De tror da, vi sejrer tilsidst?" "Sejre", svarede han, "det er for lang Tid siden opgivet. Kan vi blot naa til en Fred, der ikke helt ødelægger os, maa vi være glade«. Tavshed - og det var en Tysker.

12. A pril. Hvor er det drøjt med dette nye Paabud, at vi kun maa skrive tysk til Danmark. Netop nu. Men det ligner dem, og saa undres de Mennesker, at de ikke er elskede nogetsteds. Nu har jeg afsendt Brev og Kort, det tager jo meget længere Tid end ellers, og daarligt tysk er det.

13. A pril. Paul atter indkaldt, skal rejse imorgen til Slesvig. Hvorledes kan det dog forklares, i hans.Papirer staar: "Dauernd 
untauglich". Muligt, at han kan komme hjøm igen. Stemningen trist. Vor gamle Karl Peter var her i Gaar, han har dog et rart Ansigt; han spurgte saameget efter Cathrine. Ilan kom for at takke for Hans.

14. A pril. Her kom Russere forbi, de Stakler. De var lasede og saa daarlige ud, de gik i Traskostøvler, deres egne Støvler og Pelse har Tyskerne taget. Hvor det ligner dem?

15. April. Atter Politiet her for Korn-og Svinespargsmaalet. Det er Optælling over hele Linjen, hvad nytter dog det. Som en Karl sagde: "De stikker alle tilside". Ligesom han sagde om nogle stakkels magre Heste, vi saa: "Ja, det er jo Folks egen Skyld, hvorfor stikker de ikke til dem, det er ingen Synd“. Og Rose og jeg stikker til dem, saa godt vi kan.

18. A pril. Jeg længes efter Sang, Musik, Liv og Skønhed. IIvor er man dog underlig konstrueret! Paa samme Tid jeg forarger mig over andre, dukker der ('nsker og Lixngsler op hos mig selv. Jeg ræddes mange Gange for mig selv.

19. A p ril. Lest Sadekornet. Deri on Artikel af Ærkebiskop Söderblom i Uppsala. Meget smuk Beskrivelse af den vaagnende Religion og Kirke i Frankrig, og af de franske katolske Præster, les curés sac au dos, som, trods at Præstens Deltagelse i Krigstjænesten strider mod den katolske Kirkes Lare, dog lader sig indrullere i Ilæren og giver Exempel paa Mod og Opofrelse i høj Grad. Han fremforer talrige Exempler.

23. April. Fru Boysen og jeg gik den yndigste Tur til Vesterris. Paa Hjemturen opdagede vi desværre, at der flagedes. Det fordærvede egentlig alt, for mig, thi jeg kunde se paa Flagenes Mængde, at det var en større IIistorie, der flagedes for. Fru Boysen trøstede saa godt hun kunde, mente, vi havde oplevet det saa tit, at de hævede Ubetydeligheder til "glänzende Waffentat«. Gik hjem den dejlige Foraarsaften, hørte Droslerne synge i tre forskellige Haver, følte den frugtbare milde Luft forjattende, fornyende, og tænkte paa alle de mange Stakler, der denne skønne Aften laa døde og drende.

24. A pril. Bedrøvet og trist, skønt Fader ogsaa trøster det bedste, han kan; han har en lykkelig Evne til altid kun at tro en Brøkdel af Tyskernes Sejrsmeldinger.

26. A p ril. Gudskelov, det viser sig, at Sejren ved Ypres ikke har været saa stor.

27. A pril. Kort fra Paul; han er paa Rejse gennem Tyskland, men maa intet skrive om, hvor de skal hen. Kortet stemplet telzen. Skrevet paa tysk.

28. A pril. Kort fra Paul fra Worms og fra Friedberg i Hessen. Gud ved, hvad de skulde dernede, og hvad de skulde bruges til, aldeles uøvede som de er" Er clet for at dupere Fjenden?

29. A puil. I Aften offentligger Grenzpost Navmene paa de Hadersfolk, der har givet de stakkels Fanger (mest Russere) en 
Forfriskning paa deres Gennemrejse her i Byen, og fortaller om Straffens Størrelse. Sikken ussel, nedværdigende Fremgangsmaade. Nu er der ni døde.

30. A pril. Stadig kommer det ene Godstog efter det andet med fyldte Vogne, plomberede. Alt sendes herover. Men hvorlænge kan det vare, inden England veed det hele, og saa kommer Gengældelsen, og Gud skal vide, den er fortjænt. Vi har her hørt en hel Del i den Retning.

5. Maj. Brev fra Paul paa tysk, de maa ikke skrive andet. Han beder Rose ogsaa skrive tysk, da han ellers ikke faar hendes Breve, ligeledes er baade Kort og Breve fra ham stemplet "militärisch geprüftı. - Man flager [osv.]. Grenzpost revner af Skadefryd og Hoveren.

6. M a j. Thomsen hjem fra Berlin. Han mener, de har ingen Nød endnu, men Stemningen er nu langt fra Begejstring, der skal kun lidt til, at den nærmer sig til Modstand imod Krigens Varighed. 8. M a j. Man flager igen. 9. M a j. Flagene atter. Det var et stort engelsk Dampskib, de havde torpederet udenfor Irland. 10. Ma j. Det er Lusitania. Hele Verden er forfærdet. 11. M a j. Man flager i Dag for de store Sejre i Galizien. Fader tror, det meste er lavet for at influere paa Italien, som er meget ophidset nu. 25. M a j. Ringning.

29. M a j. Rejsetelegram i "Politiken« fra Karl Larsen fra Berlin og Felten. Alt var naturligvis f. f.: Stemningen, Soldaterne, Frdemidlerne, alt. Jeg synes, de maa laese den som en vis Person Bibelen, naar Cathrine kan skrive, at der næsten ikke er et Nummer af Bladet, der ikke udtrykker sin Sympati og Kærlighed for Frankrig, eller for de allierede. Jo, jeg takker.

30 . M a j. Fadcr i Aabenraa. Havde en Del at fortælle fra Generalforsamlingen. Kr. Thomsen var hjemme paa ti Dages Orlov, han saa rask ud og saa fornøjet, han bliver uddannet til Officer i Königsberg. Hanssen fortalte, at i Berlin var Stemningen ikke saa god, som Pressen gjorde den til, Massedemonstration af Kvinder foran Rigsdagsbygningen, raabende: "Wir wollen den Frieden". De blev drevne bort af Politibetjænte, der var forfardelige Tumulter, Bladene havde faaet Forbud mod at lade det kommme frem. 1. Juni. De flagede i Byen. 2. Ju n i. Man flager.

3. Juni. Hørte i Dag om en ældre afskediget Lærer, der paa en Mellemstation talte med en Mand, der fortalte om en Bekendts Søn, der var gaaet med i Krigen som frivillig. Læreren sagde: det kunde han da ikke forstaa; naar man skulde det, var det en anden Sag, men gaa med frivillig, det hørte der noget til. Paa den Ytring blev han straks arresteret, ført til Flensborg (han skulde have været nordpaa), og der har han siddet i tre Uger. Det er H. P. Hanssen, der har faaet ham fri. Derefter besvarede han sig til Landraaden, men fik det Svar, at den Sag var «entledigt «.

4. Juni. Nu har vi intet mere til Dyrene. Brød og Mel 
skrækkeligt. Stor Flagning og Klokkeringning. Christines Broder arresteret, han er Bankdirektør i Rødding, beskyldes for at have hjulpet Lycke. Der foreligger heldigvis intet Bevis mod ham. Bro. deren, der er deserteret fra Flensborg, er lykkeligt kommet over Grænsen. Tandlæge Sack, der er Reserveofficer og har et Kompagni at eksercere med, var forrige Dag ude paa Øvelse med dem ad Fjelstrup til; da de kom paa Hjemturen, sagde han til dem: "Singet nun, Leute«, men ingen gjorde det, det havde været en streng Tur, og de var ikke tilfredse. Saa kommanderede han omkring, og nu maatte de tilbage og fik en ordentlig Stroppetur og kom forst hjem henad $4 \mathrm{i}$ Stedet for 12-1 og fik intet at leve af $\mathrm{i}$ den Tid. Det var gamle Folk, og saaledes bliver de chikanerede, det er egentlig uforskammet, men vent, til han kommer i Felten.

9. Juni. Karen, der er kommet hjem efter at have besagt sin Mand i Sønderborg, er meget forknyt. Jørgen skulde nu afsted, men til hvilken Front vides ikke, og Soldaterne faar det heller ikke at vide, førend de er der, og saa faar de Paarørende først Efterretning. Der var en Masse Koner med Toget for at tage Afsked med deres Mænd, og de blev just ikke paa det allerblideste behandlet af Eonduktøren, men en var der iblandt, Karen sagde, en køn kraftig kone $i$ Cerne, vistnok af en bardre Stand, hun tog Bladet fra Munden $r z$ sagde, hun lod sig ikke buhandle saadan, hun rejste i sit lovlige Erinde for at se til sin Son, og hun var ikke bonge for at sigc, at (let var det varste Regimente, der blev fort nu; vilde de kaste hende i Forngsel, saa værsaagod, hun kunde ikke lide mere, end hun alleredo havde gjort. "Min yngste Son har jeg fatat hjem som Krøbbel, og den anden, som er gift og har Børn, har de nu taget, mit Korn har de taget fra mig, mine Kreaturer sulter, jeg har selv manttet baade pløje og saa, min Mand døde i Fjor, og jog har maattet hjalpe mig med en bitte Dreng, og Indkvartering har jeg haft, tyske Officerer, de tog min Senc og sagde, jeg skulde ligge i Halm, men det fik de mig dog ikke til. I otte Nætter sad jeg med Klæder paa i en Stol og sov, og Mad lavede jeg til dem, men i e Halm fik de mig ikke," kom det tilsidst helt triumferende; "men Gud give, der snart kunde blive Regnskab gjort, og at min Jord kan blive dansk og A begraves deri." Karen var helt bleg og bevaget, da hun fortalte det, og jeg følte mig kold og varm.

10. ! u ni. Brev fra Paul, som han har faaet sendt underhaanden. Deri tager han Bladet fra Munden $o g$ siger, Tilstanden er næsten uudholdelig, saaledes bliver de trivellerede og kommanderede og indeksercerede. De er paa Benene fra $3 \mathrm{~cm}$ Morgenen, imellem til 8 Aften, de er under streng Kontrol, alle deres Breve bliver læste, ogsaa dem, de modtager; er der en uovervejet Sxtning i dem, straks Stroppetur, Ekstratur. De maa ikke tale eller skrive dansk, de onsker alle: Hellere til Fronten end saaledes pines. Rose meget forknyt. 
11. J u n i. Stakkels Paul, det er haarde Tider for ham; vi har sendt Pakker i Dag, ogsaa til vor Landstorm Jensen. Jørgen er endnu ikke kommet afsted fra Sonderborg, Karen har haft Brev i Dag.

12. Juni. Flagning. Man taber Modet tilsidst. Hver Formiddag har jeg nu den Lidelse at se Dyrene sulte; til Hønsene har vi nu aldeles intet; vi koger lidt Kartofler, men hvad forslaar det. Køerne er gudskelov ude, men de lider meget af Kulden, vi har i denne Uge haft Nætter med Frost henad Morgenstunden. Til Hestene har vi kun et Minimum Havre, ellers maa de nøjes med Halm og Grøntfoder, og til hver Bid Brød, Rose og jeg stikker til dem, bliver der set skævt. Svinene faar kun Mask og Mælk og ligner Streger. Nej, det er en Ynk.

18. J u n i. Der er Nattefrost. Sirden har lidt frygteligt overalt.

22. J uni. Fru Roose fortalte, at ved Missionsmødet i Hoptrup havde hun hort flere Bønder sige: "Lad os bare faa Misvækst, des for er vi fardige med Krigen«. IIxrte i Dag, at der var hele Jarnbanevogne med Ammunition og Patroner i Voj'ns oy Jels og Rødekor'sVogne i Masse. Vagten ved Grænsen er fordoblet. Hvad betyder monstro dette? Udtalelser fra Jylland, særlig fra Kolding, vidner om, at Fortyskningen har bredt sig umaadelig, nu er det saavidt, at man ligefrem siger: "Hvad skal vi med Sønderjyderne, der følger kun Kævl og Strid med dem." Skrumsager har nok rigtig læst Appel Teksten ved et Møde i Askov.

23. Juni. Klokkeringning [osv.]. De stakkels Russere i Fangelejren, hvad har de vist lidt; for hver, dor lykkelig kommer over Græusen, takker man Gud; af de sidste tre, der flygtede, blev desværre en skudt, fordi han ikke vilde stoppe. 24. Juni. I Nat har det frosset, Rim allevegne tidlig i Morges. Hvor bliver den gode Høst af, som Tyskerne skal bruge netop i Aar. Soldaten fortalte, han var hjemme i Vojens paa Orlov, at deres Skyttegrave efter en fortvivlet Kamp ofte har varet halvfulde af Blod og afhugne Lemmer og døde Folk. IIan sagde det ganske stille, han sagde i det hele ikke meget. 25. Ju n i. Horte i Dag, at Børnene i Skolerne har faaet Ordre til at samle og medbringe Guld- og Sølvsager; og de stakkels Unger, der intet faar hjemme, bliver uglesete. 27 . Ju ni. Horte i Dag, at der er Masser af Soldater dirigerede til Grænsen.

28. Juni. Der begynder at komme Fredstanker frem, Vorwärts forbudt, fordi den har indeholdt et sooialistisk Opraab for Fred og for ingen Anneksion. Skulde det vare, som Fader paastaar, en Manøvre af Regeringen? Folket skal vænnes til de forandrede Signaler. Tyskerne er vist egentlig desperate, og deres Overflod af Levnedsmidler og af alt eksisterer vist kun paa Papiret, $i$ det mindste er alt her knapt, utrolig knapt, Brødet ofte uspiseligt, Petroleum findes næsten ikke, maa kun leveres en Liter ad Gangen (70 Pg.). Svinekød er der intet af, Smør ikke heller, Dyrene sulter og Mennesker ogsan. De kan ikke holfe ud lange trods deres store Ord. 
1. Ju li. Man flager. 2. Juli. Hørte i Dag, at en Overlærer Katt [Kommunelarer i Haderslev] havde sagt til Børnene: "Freuet Euch, ein grosser sieg gewonnen, singet und seid fröhlich, nun ärgern sich die dummen Länen«. 4. J u li. Været i Sølyst. Masser af Soldater og smaa tyske Embedsmænd. Hvor tysk altsammen!

8. Juli. I Dag en Masse Mandskab afgaaet til Fronten. 9. Juli. Tante Christiane fortalte oprørende Ting fra Fangelejren ved Gabøl. Aldeles utilstrækkelig Forplejning og slet faar de stakkels Russere. De dør i Massevis, og man henter dem ikke til Sygehuset, førend som halvdøde, og man behandler dem ved Transporten som Kvæg. Kirkegaardene deromkring kan iklke rumme flere, nu jorder man dem paa Heden. Nu begynder Bønderne heromkring at rejse Børster ved Tanken om, at den rige Host bliver beslaglagt, og at de ikke selv maa administrere deres eget Korn, som det har kostet dem i Aar saa meget at faa saact. Der er jo ingen Folk at faa.

16. J u li. Atter en odios Kronik af Karl Larsen, han ender med at skildre sin Afrejse fra Berlin, taler om hvor forskelligt alt er fra sidste Gang, han var her, da var alt forfærdelig Uro, i alle Ansigter stod skrevet fast og bestemt: Vi skal sejre, og Læberne pressedes sammen og Hænderne knyttedes, medens nu alt er roligt, fredeligt; paa alle Ansigter staar at lase: Vi kan sejre. - Fader har faaet tilsendt fra Berlin det nye Blad "Nutiden", udgivet for danske i Tyskland, med Anmodning om at stotte det. Jeg betragter det som en Fornærmelse at faa det tilsendt, det er værre end Grenzpost.

1 8. ! u li. Klokkeringning [osv.] [vidtløftig Skildring efter "Flensborg Avis" af en Landsretssag mod Gaardejer Ingemann Schmidt af Tiset for at have udspredt falske Rygter. Han var anmeldt af en Datter af Gæstgiver Gaarde i Arnum. Tre Maaneders Fængsel.] 21. J uli. Klokkerne ringer [osv.] 22. Juli. Lise har skaffet os lidt Korn til Hønsene, sikken Glæde det bliver, ja man er nøjsom nu. Pakket og afsendt til Soldater.

24. Juli. Flag allevegne. Saa Pastor Prahl med højstegne Hannder hejse sit Flag, det gav et Stik i mit Hjrerte. In Mrngde Soldater rejste i Dag. Lise og jeg kom midt ind i det hele, en Trængsel uden Lige. Soldaterne fulgt af det halve af Byen og smykkede med Roser, og Buketter blev der stukket ind til dem af Damer og Børn. Nu horte vi, at 12-13 Aars Piger af Lærerinden havde faaet Ordre til at følge Soldaterne, og de, der medbragte en Pakke til dem, fik to Timer fri og fri for Lektie. Susse Refslund [nu Adjunkt i Ribe] havde ingen Pakke med og fulgte heller ikke. Hun og on til, som havde glemt sin Pakke, blev lukket inde, og da Pigebørnene kom tilbage, omringede de Susse og spurgte: "Warum hast du keine Liebesgabe mitgebracht . Hun svarede kun det, om de saa spurgte hende nok saa meget:" Weil ich nichts habe", og der var ikke mere at faa ud af hende, men saa raadslog de andre lidt, og saa hed det sig: "Wir wollen nicht mit dir spielen, du bist zu dänisch«. De andre danske Pigebørn i Klassen havde 
Pakke og Blomster med og fulgte Soldaterne. Men sikke Prdagoger de er. - Man flager i Aften, og Klokkerne ringer, og der er Sang i Gaderne.

26. J u li. Sammen med en hel Del gamle Karle rejste Mads i Morges; han var meget forknyt og hans Kone ikke mindre. Han kom til Altona. Det er ingen Spog for en Mand over 40, og saa stiv som han var af Arbejde. Har faaet en Mand paa 55 til at passe Kreaturerne, men han bor helt ude ad Aastrupvejen, saa det er ikke saa let, men man maa jo endda være glad ved at faa ham. - De flager stadig.

1. A u g. I Dag er det et Aar, siden Krigen begyndte. I Dag skal der være stort Gøgl paa "Nordermarkt, Enthüllung und Nagelung des eisernen Kreuzes«, begynder med Tedeum og saa Kaiserhoch osv. og Taler. Der er Guldsøm og Sølvsøm og Jernsøm, som skal hugges i Korset, og der betales derefter, og Navnene bliver indskrevne i "das goldene Buch", der skal overgives til Efterverdenen, undertegnet "Ausschuss der Kriegshilfe", og der er flere danske Mænd i dette Ausschuss. Det regner i Dag, saa Festen begunstiges ikke.. Her er en Masse Rekrutter til Uddannelse, uafladelig hører man Skraalen og Sang. Der bliver samlet ind i alle Byer til "Kriegshilfec. Nu er alle Kobber-, Messing- og Nikkelting i Køkken og IIusvæsen beslaglagt.

2. A ug. "Nordermarkt" lignede en Markedsbutik, der har ngsaa været Musik i Dag, Landboerne var jo inde [Mandag, Torvedag i IIaderslev], og de vilde vel ogsaa have deres Navne foreviget og deres Pengepung lettere.

3. A ug. Frk. Stemann her paa Visit. Vi havde intet at tale om. Hun var opfyldt af Harme over de nederdragtige Italienere. Vi svarede ikke. Man kan ikke tale med Tyske nu. Men de lever alle i den lykkelige Tro, at de er saa velkomne og kan sige alt. De tanker slet ikke paa andres Følelser. Naar de udstrækker Haanden, har vi bare at tage den og være lykkelige derved.

4. A ug. Møllers Søn, der var hjemme paa Orlov, havde vieret et Besøg paa "Modersmaalets « Kontor, det er blevet angivet, den højstkommanderende her kaldte ham op, gav ham en Røffel og fratog ham de Dage, der endnu var Rest af hans Orlov. Han rejser i Dag.

5. A ug. Springer her fra Hamborg, Møde i Retten. Amtsdommeren begyndte straks med at gore Fordring paa, at Offentligheden skulde udelukkes. Faders Advokat, som straks skuede Uraad (Meningen var, at de vilde gøre Sagen fra en simpel Fornærmelsessag til en storpolitisk Sag, hvor Strackerjan kunde skyde sig ind under, at hans Følelser, hans Fædrelandskærlighed, var Aarsag i alt, hvad han havde sagt og gjort, og derfor slippe med en lille Bøde og maaske slet ingen; de er kapable til alt i denne Tid) gjorde straks Indvendinger derimod, og saa vægtige, særlig støttet af Købmand 
Frees, som, efter Grenzpost, "eine bei vertraulicher Beratung des Gerichts gefallene Ausserung unbefugt im Sitzungssaale erzählter. Saa nu er Sagen opsat og gaaet til Flensborg, som nu skal dømme, om Offentligheden skal udelukkes, og der kan gaa lang Tid hen. Strackerjan havde indleveret et Aktstykke paa 16 Sider lige før Retten var sat, som altsaa hverken Dommerne eller Fader eller hans Advokat havde gennemlæst, 16 tætskrevne, knudrede Sider, man skulde tro Manden var lidende af Monomani, stadig dukker Tennisspillet op i Aktstykket og "unsere tapferen Truppen, ernste Zeit, Vaterland" osv. Saa bliver Lise, hendes Moder, H. P. Hanssen citeret som Vidner. Hele Skrivelsen er Gentagelse af gamle Beskyldninger, og jeg synes, temmelig forvirret. Strackerjan er jo nu ansat i Bryssel: de stakkels Belgiere, kun »zur Zeit» i Haderslev. Fader er tilfreds med sin Advokat, men mener, at det kan trække i Langdrag efter Strackerjans og Dommernes Forgodtbefindende, der er jo ingen Retfærdighed at faa i disse Tider.

6.-7. A ug. To slemme Dage med Flagning og Klokkeringning og Halløj. I Højskolehjemmet blev en Soldat, en dansk Soldat fra Sundeved, kommanderet til at hejse det tyske Flag. De havde naturligvis valgt ham, fordi han var dansk. Paa Harmonien var der ogsaa beordret tysk Flag. 8. A ug. I tre Dage har det tyske Flag vajet over Harmonien. [9. A u g. Strackerjan fik fra Generalen i Altona et Forbud og blev stillet under Censur.] 10. A u g. Telegram fra Paul til Rose, at han afgaar til Rusland. 13. A u g. Forbud mod at bruge Læder. Befolkningen gøres opmærksom paa, at der er noget, der hedder "Holzpantoffeln, Holzschuhe» og for Barn bare Ben, som er det sundeste. Alt Læder skal bruges af Hæren. Flødeskum er ogsaa forbudt. 14. A u g. Nu er Folk paa 43 tagne, det begynder at knibe. Paa Markerne ser det kun sørgeligt ud. Postkort fra Paul fra Eydtkuhnen.

15. A u g. I Morges kom der en 5-600 Soldater afsted. Musik paa Banegaarden. "Ansprache af Bataillonskommandøren, Hurraer og Fædrelandssang. Reversen af Medaillen Graad og Sorg hos de efterladte. Hørte, at der skal være en Mængde svenske Officersaspiranter i Lockstedt. Ved en Tennis røbede de deres Modersmaal for en Del Nordslesvigere, men da de mærkede, de blev forstaaede, har de derefter kun talt tysk. [Det var ikke Svenske, men Finner.]

16. A u g. Den væmmelige Karl Larsen har en Kronik i »Politiken " fra Østrig. 18. A u g. "Es ist verboten" at skrive mere end to Sider til det neutrale Udland, og Skriften skal være tydelig og stor, og Konvoluten maa ikke være foret.

20. A u g. Flagning [osv.]. 21. A u g. Endnu Flagning. Regn og atter Regn. Høsten bliver nydelig, det er det eneste Gode. 25. A ug. Paul er i Nærheden af Kovno. Bankbestyrer Lycke fra Rødding er nu løsladt af Fængslet. Han saa meget godt ud, skønt han har tabt 20 Pund i Fængslet, han fortalte, at han var i Fangedragt, 
maatte sove paa Briks, som var haardt og koldt, og maatte flette Maatter, et bestemt Kvantum skulde han have færdig, hvis ikke blev der trukket af paa hans i Forvejen sparsomme Ration. Han havde imidlertid i disse Maaneder tjent fire Mark. Han var jo straalende glad, de havde ingen Bevis imod ham.

26. A ug. I Aften har Klokkerne ringet [osv.]. 27. A ug. Gentagelse ("allenhöchster Befehl«). Hele Dagsbefalingen et afskyeligt Sammensurium af Gudsbespottelse og Hovmod og - Indskræenkethed. Tyskerne dementerer Russernes Sejr i Rigabugten, og de har heller ikke mistet noget Skib. Bødkerens Søn fra Vojens, som er med paa "Moltke", har telegraferet hjem, at han var reddet. Se, det er dog et Bevis. - Hvor er dog Socialisterne blevne smaa og tamme under denne Krig, de lader dem byde alt. Fre være dog Liebknecht.

2. Sept. H. P. Hanssen og Søn var her i Dag. Underligt at se Sønnen i tysk Lieutenants-Uniform. 10. Sept. Ringning [osv.] 11. Sept. Man flager [osv.]. 12. Sept. Tur til Sønderballe. Kystvagt: Et lille Hus bygget paa Toppen af en høj Skrænt, kaldet Waldkater, to pæne Soldater med Lyst til at snakke, vist fra Rhinegnen, betroede Lise, at deres meste Bestilling var at passe paa Undervandsbaade, og at ingen af Russerne flygter i Baad. Saa deres Vinterhytte i Skoven med Kakkelovn og det hele. Aflesning hver to Timer.

14. Septbr. Brev fra Paul. Hvor de døjer meget ondt. Gudskelov de to Venner [J. P. Dahl] er sammen, det or ligesom en Beroligelse. 19. Se pt br. Klokkerne [osv.]. 22. Se ptbr. Schmidt i Kreditbanken er gaaet over Grænsen; man siger, der er mange, der gaar over i denne Tid. Petersen i Forretningen i Vojens er taget i Dag, og Gud ved, hvor længe vi beholder Thomsen. Rose maa jo nu tage fat derude. Jeg gaar og er i Kamp med mig selv hele Dagen i denne Tid. Vilde saa gerne hjem, og jeg tør ikke begynde paa de indledende Skridt af Frygt for at blive puttet i Arrest, da jeg ikke har Passpørgsmaalet i Orden. Og saa er der den Tanke, hvis der skulde komme meget svære Tider her, hvorledes vilde jeg saa være tilmode i Kobenhavn. Det er ikke let.

26. Septbr. Fader kom hjem fra Harmonien med godt nyt [Tyske Tab ved Lille tilstaaet af Grenzpost]. Saa kommer der naturligvis en Masse Sejrsmeldinger fra forskellige Steder, men -det er dog Nederlag et Sted i det mindste. 27 . S e p t b r. Hvor var vi glade og taknemlige i Gaar Aftes. 28. Septbr. Hurra, Fransken har Sejr vundet, brudt de tyske Stillinger over en Front paa $25 \mathrm{~km}$ og engelsk Sejr ved La Basse. Vi er saa glade i Dag, det er som en uhyre Byrde er blevet lettet. 29. Se p tb r. Gudskelov endnu gode Efterretninger fra Vestfronten. 30. Septbr. Men der er jo langt igen.

1. Oktbr. I Dag er der afgaaet en Masse Soldater herfra, 
ganske unge; de sang og raabte Hurra ved Afrejsen; nu skal de, som Christine sagde, hen at slagtes. N. N. er blevet taget paa Session, og han har en Gummifod, alt tages, Krøblinge, Halte, alt. 2. Okt br. Angst for Tilbageslag.

9. Oktbr. Fader er storartet til at holde Modet vedlige hos os alle. - Hvis Gud overhovedet har noget med alt det skrækkelige at gøre?

14. Oktbr. En vrovlet og intetsigende Kronik af Karl Larsen; man mærker ret, hvor han er ilter og gal i Hovedet over de dygtige Modstandere, der har læst ham Teksten. Han citerer baade Sven Lange, Brandes, Rubin og til Overflod en Belgier med et fordagtigt tysk Navn, Willem Vogel, og Rodin [mon Rolland?], men det nytter ham alt intet.

16. Oktbr. Nu er det rent galt med Mælken, der er intet at faa ved Malkevognene, nu skal der Kort til. Thomsens med tre Børn og to Piger og tre Voksne faar tilsammen een Liter. Nu skal der Hojestepriser, men det vil ikke hjælpe, siger Fader. Ja det er strenge Tider, og det vil blive endnu værre. 19 . Oktbr. Nu bliver det vanskeligt at faa Sukker. Nu er der Højestepriser paa Smør, paa Kartofler. Last Johan Bojers Kronik, Brev fra Paris, forfærdelig gribende Skildring af de stakkels franske blinde Soldater.

21. Oktbr. Der er Forbud mod Udførsel af Smør i Slesvig og Holsten, berører Fader meget. De har jo baaret dem forfærdelig dumt ad, sat som Højestepris 2,60 i Hamborg, 2,80 i Berlin. Følgen at der ikke kom Smør til Hamborg; det vil de nu gare godt igen ved dette Forbud. Men de kan ikke overholde dette Forbud længe, mener Fader, de maa hæve det.

22. () k tbr. Meddelelse fra Pet॰r Petersen [tidligere Kusk paa Damager] om Hanses Død. Jeg er meget bedrøvet. Lille Hans, at han skulde dø og begraves i Rusland. Hele i Fjor Vinter laa han i Skyttegravene i Frankrig og skrev altid saa fornøjet, saa blev han syg, kom paa Lazaret, derfra har han skrevet og saa sendte han et Kort fra Rusland, og det er længe siden, men vi kunde intet sende ham, da Trafikken var standset, de tog ikke mod Pakker her. Han var en af de lovende unge danske herfra. Nu synes jeg, vi kunde have sendt ham langt mere. - Blev telefoneret i Dag fra Raadhuset med Forespørgsel om mig; jeg tænker mig, de vilde være alle ovarflodige Spisere kvit, saa jeg kan vel vente min Udvisningsordre. Paa en Maade vil jeg gærne hjem, paa en anden Maade gruer jeg for at være borte, hvis her hænder noget. Og det hele tilspidser sig mer^ og mere. hernede.

23. Oktbr. God Kronik af Anker Kirkeby om Forholdene

24. Oktbr. Fader fortalte, at den unge Spàth, Frees og nogle andre havde siddet i Centralhotellet og drukket en $\emptyset 1$ og snakket om Forretninger paa dansk. Späth, der er hjemme paa Orlov og 
i Uniform, rejste sig naturligvis og gjorde Honnør, da nogle Officerer gik forbi deres Bord; den ene lyttede lidt og kaldte ham saa til Side: "Sie sprechen Dänisch"? "Ja, es sind gesohäftliche Sachen". "Wenn Sie Dänisch sprechen wollen, so wählen Sie einen anderen Platz, hier wird nur Deutsch gesprochen. Abtreten." Ja det er nydelige Forhold. Den yngste Christiansen, som har ligget her paa Kasernen, fortalte, at det var strengt forbudt at tale sammen paa dansk, men til at fylde deres Skyttegrave duer de danske Nordslesvigere, til at kæmpe og desværre - dø.

26. Oktbr. Kort fra Paul. Han har faaet et Skud i Foden og er nu paa Vejen til Lazarettet. Jeg blev forst meget benovet, men de andre tog det som et Held. 29. O k tb r. Man flager. Man ser tyrkiske og bulgarske Flag. $30.0 \mathrm{ktb}$. Masse Forandringer med Hensyn til Levnedsmidler, det bliver knappere og knappere. Man taler om store Troppetransporter til den danske Grense. Hvad mon de venter, Englændere eller Danske? 3. Novbr. Slagtet to Svin. Fader mente det var urigtigt, frygter for Beslaglæggelse. 4. Novbr. En mærkelig Slagtedag. Slagteren kom slet ikke for at skære Svinet ned og partere det, saa vi kunde ikke gøre ret mege: : Dag.

5. Novbr. Jeg tror, mine hvide Haar skyldes Belgien og Reims, altid er mine Tanker der.

6. Novbr. Man flager. Hørt af en paalldelig Mand, at Tropperne i Berlin paa Kasernerne af deres Officerer har faaet Ordre til at skyde skarpt i Tilfælde af Oprør; de frygter det altsaa. God Artikel af Victor i Nationaltidende, kendte straks hans Maade at skrive paa, fik det bekræftet i Dag, da Cathrine sendte Nationaltidende. Færdig med det vigtigste af Slagtningen. Gudskelov, jeg cr træt.

7. Novbr. Nu er Hejmdal forbudt nogle Dage, Gud ved, hvormed den har syndet. $\mathrm{Og}$ at Folket taaler at blive behandlet som uartige Barn. 8. Novbr. Nu er der kommet yderligere Pastvang, nu kan næsten ingen rejse.

11. Novbr. En bevæget Dag: Sagen Strackerjan. Advoliaten fra Hamborg kom allerede i Morges, drak Kaffe med. Rose, Lise og Moder paaklædte fra Morgenstunden af, der kunde jo være Tale om at blive tilkaldte som Vidner. Vognen holdt forspændt mange Timer for at bringe dem derhen. Ved Kaffebordet afleverede Advokaten det tyske Program og det var sandelig tysk, rigtig Munden fuld. Naturligvis gik de lige til Konstantinopel, og der kunde de forsyne dem med alt, der var Proviant og Kobber og Fabrikker nok, og nu tog de jo Riga og tvang Russerne tilbage allevegne, og saa tog de jo ordentlig fat paa Vestfronten, thi Havet maatte de have, og Verdensmagt vilde de være. Det kogte i mig, men jeg dyede mig, og vi sad alle i Andagt og hørte paa hans Svada. - Naa, selve Sagen blev naturligvis udsat, og Strackerjan forlob sig i Retten, saa vor Advokat maatte sige til ham, at han skulde opfore sig ordentligt, 
han rendte nemlig frem og tilbage og knipsede med Fingrene i Luften, det saa helt latterligt ud. Altsaa efter et Aar og tre Maaneder lige vidt. Ganske pæn Mand, Faders Advokat, saa meget ung ud; men en ægte Tysker. De havde længe ikke spist Smør hjemme hos dem; i store Byer kniber det sikkert paa alle Maader, men da Bladene er saa strengt censurerede, kommer der intet frem.

13. Novbr. Nu er det meget vanskeligt at komme over Grænsen, de har nægtet Fru Outzen Pas til Kolding, hun maa give Ansøgning ind om det, motivere det med, at hun skal ned at tale med sin Svigerfader om Forretninger, hendes Mand [nuværende finsk Konsul Outzen] er nu i Bryssel, har været ti Dage i Skyttegravene og haft det strengt og set meget.

14. Novbr. Læst "Klokke Roland" af Johs. Jørgensen, udmærket Bog, saglig og slaaende og med ætsende Ironi og skrevet med brændende Hjærte og Harme og Foragt og dybeste Medfølelse. Læste den næsten $\mathrm{i}$ eet Aandedræt. Rose havde købt den hos Boghandler Nielsen, og jeg fik Lov til at læse den først, det var pænt af hende. At Nielsen har turdet føre den Vare! Tyskerne skulde læse den.

15. Novbr. Hilsen fra Victor og Cathrine gennem N. N..; han var ikke tilfreds med deres Standpunkt.

16. Novbr. Brev fra Paul. Han er nu flyttet til et andet - Lazaret, er blevet renset og sikriver meget tilfreds med Forholdene, tænk at være vasket, faaet rent Tøj, blevet af med Utøjet og faar en god Forplejning. Tante Christiane har i Dag faaet et Brev fra Kai [Dattersøn], hvori han taler om de danske Sønderjyder. Det er blevet rettet af Censuren med blaa Blyant til wtyske Soldater o og "danske Sønderjyder" streget over. Her ha r man da Bevis paa, med hvilken Nøjagtighed Censuren læser Brevene. 17. Novbr. "Bussund Bettag «. Ja de har i Sandhed nok at gøre Bod for.

19. Novbr. Nu er det meget knapt med Petroleum, jeg gruer for den Tid, da jeg ikke kan tande min Lampe. Luftskibshallen ved Tønder er brændt og den store nye Zeppeliner med, lige ankommet, skulde være brugt.til Londonstur, desværre en hel Del uskyldige Mennesker dræbte, hvor mange vides ikke. Grenzpost tier det hele ihjel.

21. Novbr. Kl. 7 kom Töpfer [Julius Nielsens Smøraftager i Magdeburg] og Thomsen. Töpfer ældet og afdæmpet, han har tre Sønner med i Krigen; han fortalte om Uroligheder paa Grund af Smørmangel i Magdeburg, havde stormet og molesteret et af hans Udsalg; han saa lidt pessimistisk paa det hele, men drømte dog endnu om, at de vilde gaa til Konstantinopel, derfra med den nye Bane til Suezkanalen, bemægtige sig den og derved spærre Vejen for Englænderne, medens de selv forsynede dem med alt.

22. Novbr. Der var en ganske udmærket Artikel af Dr. Fr. Böök $i$ et svensk Blad om Danskerne i Verdenskrigen, deri mærker man tydelig de svenske Sympatier for Nordslesvigerne og Dan- 
mark. Anderledes med Bestyrelsen for Uddelelsen af Nobelpræmien, en skal være bestemt for Romain Rolland, som vitterlig er tyskvenlig og bliver forhaanet af sine Landsmænd. I den allersidste Tid, medens hans Folk bløder og lider, skriver han til Gerhard Hauptmann: "Vi Brødre i Frankrig, i Tyskland, i England hader ikke hverandre trods alt, hvad der skrives i Pressen«.

24. Novbr. Indkvartering; han er fra den hollandske Crræuse, gift, tre Børn, seks Køer, tre Heste, pæn Ejendom, har været inde siden Marts.

25. Novbr. Man flager. Outzen har fortalt, at i Bryssel, hvor han er, maa Soldaterne kun gaa to og to, og paa Restaurant maa de have det ladte Gevær ved Siden af dem. Det er vel paa Grund af, at de er saa elskede, eller som Lise siger, er det en List for at ophidse Soldaterne mod Byens Befolkning. 26. Novbr. Paul er kommet til et Lazaret i Wittstock, hvor han har det godt; bare nu ikke Saaret vil læges for hurtigt. Min kære Overlærer Schmidt [Gymnasielmrer Schmidt, Horsens, Udgiver af Larebog i IHistoric] død, der er saa mange Frindringer, der bliver levende.

27. Novbr. Brev fra Cathrine, at mine Blomster nu alle er døde eller tilintetgjorte; jeg er i Grunden meget bedrøvet, havde dog haft et lille Haab. Hvor mange Gange har jeg ikke tænkt paa mine stakkels Blomster, og hvor sært det end lyder, haft Samvittighedsnag over at have overladt dem til ukyndig og ukærlig Pleje. Jeg har ligefrem maattet ryste Tanken af mig, saadan har det ofte pint mig. Det er næsten nu som en Lettelse for mig, at de nu ikke lider. - II. P. Hanssen udtalte, at i Stedet for at hente Vognladninger dernede fra [fra Balkanhalvøen], gik den ene Vognladning efter den anden herfra ned til Tyrkerne, overhovedet var der intet at faa derfra. Løgn og Løgn er det hele. - Brandes skriver, at $i$ en Fortale i den svenske Udgave af det tyske Skrift "J'accuse" har H. S. Hallberg citeret Brandes fra 1881 i hans Bog om Tyskland, og man faar ved at læse disse Anelser om Verdenskrigen sin Tanke bekræftet, at alle store Aander momentvis har Følelsen af, hvad der vil ske 1 Fremtiden, de er clairvoyante.

28. Novbr. En ganske mærkelig Bekendtgorelse fra Overpræsidenten Moltke er i alle nordslesvigske Blade, slaar de Rygter ned, der or i Omløb, at noget af Slesvig skulde tilbage til Danmark, siger, de savner ethvert Grundlag og at Slesvig er og vil blive tysk. Hvorfor mon det er gjort nu? Hvorfor røre ved det Sporgsmaal? Fader mener, at der kan være Tale derom, netop naar de dementerer det. 29. Novbr. Ingen Petroleum, det er drøjt, sidder ved et Lys, der knap nok kan kaldes Lys. 30. Novbr. Grenzpost stort Referat af Indvielsen af Præparandanstalten, hvortil Moltke var indbudt; han og Borgmesteren og Provsten var Talerne. Med Hensyn til den Ungtom, der skulde oplæres i den Bygning, var Løsenet hos dem alle tre: "Gehorsamkeit und Ordnung", der var slet ikke Tale om at 
udvikle Menneskene, nej kan de bare læeres til at Jyde og have deres Sager i Orden, er det evig godt, og saa bliver de alle i een Form ferniscret med lidt Kundskaber, men alle overbeviste om, at de er de. eneste, der duer noget.

1. De c br. Flagning [osv.]. Nu er Kursen paa Kronen her 40, hvad skal det hele dog blive til, Fader mener Ruin, Tyskland kan ikke undgaa sin Skæbne. Nu er her kommet en Tvangsforordning, at alle unge, Lxrlinge, Handelselever, sk al deltage $i$ noget, der hedder "Jugendwehr", Øvelser hver Søndag for at de hurtig kan være ngnede til Soldater. Som om det var Livets Udvikling hen imod Idealet: Soldater. Det er Skade, at Modrene ikke kan føde blot Drenge, helst fiks og færdige Soldater. De uægte Børn er komne til Fre og Værdighed, jeg tænker mig, Staten indretter en Produceringsanstalt. Noget maa der gøres, deres stakkels Ungdom har de jo næsten mistet eller faaet lemlæstet.

4. D e c b r. Al den Lidelse og Ulykke maa de engang staa til Regnskab for, det nytter dem ikke. - Sigrid Nissen [senere gift med (len kendte Naziprast Peperkorn] er i Sonderborg at besøge sin Tante, Fru Beyer, hvis Mand er ved Fronten. I Dag kom Gendarmen for at spørge efter hende, Fru Nissen ængstelig, rejst til Sonderborg. Det er en forfærdelig Skæbne, der har ramt Familien Beyer, Fru Nissens Brødre. Først var den ene arresteret seks Maaneder. Lige som han kom ud (de kunde ikke overbevise ham om noget), blev han taget til Soldat, han var hos Landraaden for at beklage sig og denne syntes jo ogsaa, det var haardt og lovede at interessere sig for ham, men det hjalp ikke, han maatte afsted. Den anden havde været Soldat et Aar, kom hjem med Orlov, samme Aften blev han arresteret og ført til Berlin, de har intet hørt fra ham senere. Den tredje, ældre, blev nu for nogle Dage siden taget og fort bort, de ved ikke hvorhen. Den gamle Fader, over 70, sidder i Fængsel i Sønderborg. Man mener, at det hele skyldes, at den ene fra Fronten har skrevet til sine Brødre og sagt, at det hele dernede var saa rædselsfuldt, at det var bedst for dem at stikke over Grænsen hurtigst muligt. I Dag var Schmidt, Vojensgaard, her, han var en hel Del altereret, der havde varet Husundersøgelse hos ham af Kommuneforstanderen, som ogsaa havde fortalt ham, at alle de Breve, han modtog, blev laste. Han maa jo være mistænkt. De havde intet fundet hos ham, men Schmidt var dog ikke rolig. Schmidt fortalte, at den ene af Fru Nissens Brodre var idømt fem Aars Tugthus, man skulde ikke tænke sig det muligt. Didas [Datter af senere Borgmester C.hristensen] Broder har faael Bøde, fordi han ikke er mødt forrige Søndag ved "Jugendwehr«? Ovelser, det er altsaa complet Tvang; det hele er med militært Snit, en Slags Uniformshuer har de paa, tyske Sange synger de - og dertil bruges Søndagen, jeg har set dem, og det tvinges altsaa danske unge Mennesker til.

6. De c br. I Dag har der været Gendarm hos Nissens paa 
Vojens for at spørge efter Sıgrid. Hun er i Besøg hos en Tante i Sønderborg. Fru Nissen er blevet ængstelig og rejst derned. 7. D e c b r. Fru Nissen kom tidsnok til Sønderborg for at se Sigrid fort i Arrest til Flensborg. Hun ved ikke selv hvorfor. Hun mener, det er paa Grund af et Brev, en Fætter har skrevet til hende. Fru Nissen fortvivlet. I Arresten sidder nu den gamle Fader Beyer, en Sen, en Fætter, en Fætter eller Kusine og Sigrid.

8. D e c br. Var hos Pastor [Thade] Petersen, fik en Del Adresser paa danske trængende Soldater. Hørte, at Gaardejer Peter Gad [nu i Hejsel i Rabsted Sogn], gift med en Frøken Lycke, er blevet arresteret, fort bort og Gaarden sat under Bevogtning. Den unge Kone maa hverken gaa ud eller modtage nogen, faar heller ingen Breve. Gad var først haardt saaret, det er vel et Aar siden, hans daværende Forlovede rejste ned til ham i Belgien, han kom sig, men dog ikke saaledes, at de kunde bruge ham, saa han kom hjem, men skulde saa melde sig af og til. Nu sidst, da han meldte sig, fik han tre Maaneder at lobe paa, og nu - har de arresteret ham. Ingen ved hvorfor. Og sikke Chikanerier: Pastor Petersen fortalte, at de i Fjor Jul havde sendt et lille Hæfte med Julesalmer til Soldaterne, de havde været saa glade ved dem og bedt om i Aar at faa lignende; de er trykkede og parate, men Generalkommandoen i Altona har nu fordret, førend de afsendtes, at faa Salmerne oversatte paa tysk, saa nu havde en lille Kreds af unge Piger travlt dermed, og besværligt er det jo ogsaa.

9. De c br. Sigrid maa betale $4 \mathrm{Rm}$. 75 hver Dag i Arresten, naar hun ikke vil have Fangekost. De har sendt Sengetøj op til hende. Den forste Nat sov hun paa en Briks med et Uldtæppe over sig. 13. De c br. Sigrid frigivet.

15. De c br. Nu har Landraaden kaldt Bankdirektør Hübbe til sig for at forhøre, om Kredsen kan faa et stort Laan i den danske Bank, betonet, at Danskerne her i Kredsen har været meget tilbageholdende med Hensyn til Krigslaanet, som ikke har veret Tilfaldet i Auhenjaa og Sønderborg Amt. Der or Møde dosanganentle i Dag, de tør vel ikke undslaa dem. Opraabet til at understøtte trængende. og som Fælleslandboforeningen er gaaet i Spidsen for, er ogsaa indirekte kommet fra Landraaden, som naturligvis faar sine Instrukser fra Regeringen. Alt beregnet paa, at den private Godgørenhed skal arbejde Haand i Haand med Regeringen, hjælpe den nu, da den ikke selv kan magte det. Det er vist et rart Uføre, de er komne ud i med deres Højestepriser.

16. De cbr. Pakket Julepakker nu i to Dage til Soldaterne og er endnu ikke færdig; det er saa vanskeligt at faa det, man behøver. 17. Decbr. Pakker Julepakker. Rose havde i Dag en Oplevelse i Kupeen paa hendes Rejse til Vojens. Hun sad og læste "Politiken". I Styding kom to særlig velklædte Herrer ind i Kupeen, en ældre og en yngre; begyndte med, at den ældre meget højrøstet udtalte sig om de danske Skilte og Betegnelser allevegne, det skulde der sættes en 
Bom for, her var Tyskland, og de havde alle at forstaa og tale Tysk; hvem der ikke vilde det, kunde jo forlade Landet; nej, der skulde anderledes kraftigt tages fat, og ligeledes med danske Aviser, hvad skulde det til, det var jo sunausstehlich«, og tænk, forrige Dag var der en rejsende nied, der havde den Frækhed først at sidde og grundig gennempløje en dansk Avis, for bagefter at fordybe sig i Læsringen af en dansk Bog, "solche Frechheit, es ist nicht zum Aushalten“. Den unge svarede ikke meget, men var dog af samme Mening. Dog tilsidst. da Rose sua stift paa ham, blev han lidt flov. Det hele var naturligvis møntet paa hende. Saaledes kunde jo kun en Tysker bære sig ad. Mangel paa Takt, Mangel paa Kultur, Parvenufolk. 20. I e cbr. Desværre flager de [osv.]. 21, Decbr. Fru M. Thomsen her; hun fortalte, at der i Berlin havde været flere Tusind Mennesker, der i Takt havde sunget: Brod og Fred, men var blevet sprængt af beredent Politi Unter den Linden; i Hamborg er flere Butikker med Levnedsmidler blevet stormede ag plyndrede. H. P. Hanssen har fortalt om en Samtale med en højtstaaende Embedsmand, der sagde til Slut: "Wir siegen und wir siegen - zum Tode».

24. Decbr. Juleaften. Hvorledes ser det ud med Fred paa Jorden? Ak, forrige Jul tænkte vi, ja, næste vil dog blive helt anderledes, lysere, bædre, og nu Morke overalt. 25. D e c br. Juledag. Morket ruger over Jorlen og i Hjwrterne. Havde vi ikke Fader, vilde alt have været tungere. Det er ham, der holder Modet oppe paa os trods alt. 27. De c br. Rose og Lise vil imorgen til Wittstock at besøge Paul, hurtig bestemte, 28. D e cbr. Børnene rejste imorges. Rose straalende ved Tanken om at gense sin Hjertenskær. Lise bringer Ofret med Anstand, hun syntes ikke, Rose i denne Krigens Tid kunde rejse alene.

30. Decbr. Froken Skjold fortalte om en stakkels Enke med seks Børn, meget fattig, beder om, at den ældste Søn paa 13 Aar maa blive fri for Skole for at hjælpe hende. Hun er dansk. Præsten anbefaler Andragendet, men henviser til Skoledirektøren [Kredsskoleinspektøren], der erklærer kategorisk: "Nein, er muss erzogen werden, um ein guter Soldat zu bleiben [werden!]. Og derved blev det. Det er altsaa Tysklands Fremtidsprogram, hvorfor alt andet blegner. Skidt med Kunst og Videnskab og aandelig Modenhed og

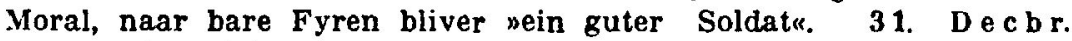
Børnene kom hjem i Gaar Nat. Paul rask og munter.

\section{6.}

1. J a n. Hørt en god Prædiken [i Kristuskirken]. Præsten læste Feltbreve højt, det er kun danske Nordslesvigere, der kan tænke og skrive saaledes, man blev bevæget og betaget af dem; det er Kultur, æg te, hvor var det sidste Brev rørende og saa ægte dansk, det bedste dansk, og saa malende og levende skildret, alt hrad denne unge Mand kæmper med sig selv - og sejrer. 
8. J a n. Fader var igaar hos Lebecks for at høre H. P. Hanssen give et lille Resumee om Rigsdagsforhandlinger. Der var en Del gode Mænd samlede, mest fra Vesteregnen: Kloppenborg, Simonsen-Flovt. I Juli Maaned var der megen Tendens til Fred blandt Rigsdagens Medlemmer; blev droftet Betingelser: Status quo men en stor Krigserstatning - men de allierede var tavse. Saa henad Efteraaret var der jo Sejr efter Sejr over Russerne. Rigsdagen kom sammen, og Situationen var forandret. Alle vilde forfølge Sejren, ingen Tanke til Fred. $\mathrm{Nu}$ er imidlertid Situationen forandret, hele Felttoget og Ødelæggelsen af Serbien finder man umotiveret. Følelsen af de uhyre Skattebyrder, som Helferich i Rigsdagen har forudsagt, virker meget trykkende, man begynder at tvivle om den endelige Sejr, man er bange for Ernæringsspørgsmaalet, da Krigen stadig trækker i Langdrag; man kan ikke holde ud saa længe som de allierede, kort sagt, man onsker Fred; men de allierede er tavse. Paa Spørgsmaal af Fader til Hanssen, hvorledes Rigsdagsmandene roligt kunde høre paa Helferichs Udvikling af, hvor udmærket Finanserne stod i Tyskland i Modsætning til Fjendernes, da de fleste dog vidste Besked, hvorfor ingen rettede Spørgsmaal til ham eller angreb hans Paastande, svarede han, at det gjaldt fremfor alt at holde Folkets Optimisme vedlige. De havde i Rigsdagen kun holdt fire offentlige Møder, men vist fjorten hemmelige, hvor det var gaaet varmt til, og hvor de ofte havde været samlede fra Morgen til Aften. Nu var der kun eet brændende Spergsmaal, og det var Ernæringen. Fra Tyrkiet og Rumænien kom intet, det var kun Løgn fra Pressens Side, men derimod gik der Vognladninger derned. Det var paa høje Tid for Tyrkiet, at Baneforbindelsen kom i Stand, der var fortvivlede Forhold. Om Socialdemokratiet mente han, at Liebknechts Parti vilde voxe sig stort, der kom daglig Masser af Breve fra Felten, og de vilde tilsidst bringe dem til at stemme mod Bevillinger, det kunde ikke holdes nede. Paa Spørgsmaal om Censuren, om den vilde blive lemfaldigere, om der vilde blive Kamp derom, exklerede han $\mathrm{Ne} \mathrm{j}$; han troede, den vilde blive, som den var.

Saa fortalte han om Forholdet til Danmark. I December var der nogle Dage, hvor der herskede megen Forbitrelse og ogsaa Lyst til Angreb paa Danmark, de havde faaet at vide, at engelske Undervandsbaade var blevet forsynede ved de danske Kyster. Der blev

- gjort Forespørgsel i det danske Udenrigsministerium, og det ikke paa den blideste Maade. Det drev over, men at der hersker en stor Tilbøjelighed til at trænge ind $i$ Danmark og forsyne sig, nu da alt er knapt, det er givet. H. P. Hanssens Søn, der er hjemme paa Orlov, havde mødt Officerer paa Vejen, der har udtalt sig i Retning af at gaa ind $i$ det gode Spisekammer og tage for sig af Retterne, saa Hanssen var ikke uden Engstelse og mente, man maatte regne med et pludseligt Kup. Forresten var der sendt en Mand til Kabenhavn, Hollmann, tror jeg han herl, som har skrevet en Bog om 
Højskolerne, han skulde arbejde for Tyskland i Danmark; han havde udtalt, at den eneste Vej, der kunde fore til Alliance, var Tilbagegivelsen af Nordslesvig. Det lod til, Hanssen fæstede Tro dertil. - Skau Petersens var der ogsaa, hun eneste Dame.

10. Jan. Man flager. 12. Jan. Nu er atter en Del af Smørret i Mejerierne beslaglagt. Fader mener, det hele vil blive taget. Vi maa alle nøjes med 1/4 Pd. om ligen.

13. Jan. I Dag en vigtig Dag. Advokaten fra Altona er kommet, og Sagen med Strackerjan skal for. Det hele gik hurtigere end ventet. Strackerjan erklarede sig rede til Forlig og gik ind paa, hvad der blev foreslaaet; sidst vilde han jo slet ikke høre Tale derom, endsige tonke derpaa: "I min Stilling, meine Vergangenheite. $\mathrm{Nu}$ krøb han til Korset, bctalte $100 \mathrm{Rmk}$. som "Sühne» og "gjorde Undskyldning ". De 100 Rmk. blev betalt til liød» Kors' "Frauenverein“, og Fru Prahl gav Kvitteringen. Advokat Springer har vist sig at vare en habil Mand, ogsaa Sagens Omkostninger maa Strackerjan betale. Vi er alle glade ved, at det nu er slut, Fader har nu friere Honder. Havde han ikke indgaaet paa Forlig, var det jo blevet en Proces, der kunde strække sig over mange Aar.

14. J a. n. Fader har faact Breve fra Flensborg med Bon om Smør; der skal laves "Butteraufstrich", et Pd. Mejerismør bliver lavet til $3 \mathrm{Pd}$. "Aufstrich", det er vist noget rart noget; siden jeg har læst, at de indvinder Fedtstoffer af Kloakernes Indhold, gruer jeg.

15. J a n. Den gode kxrlige Fru Schmirlt [Vojensgaard] er død. Jeg er bedrøvet.

18. J a n. Man flager. N. N. havd" voret paa Raadhuset for at faa Pas, men var blevet henvist til Landraaden, de kunde intet give. Landraaden spurgte, af hvad Grund hun onskede Pas til Danmark. Hun havde en Søster boende der, og hendes Datter havde været syg, og hun vilde gerne se til hende. "Lebensgefährlich?" Nej, det kunde hun ikke sige, men man vidste jo aldrig, hvad det kunde blive til. "Ich bedauere, aber ich kann keine Erlaubniss geben". - Det er galt med Mælk, Folk bestormer os for at faa. Ost er slet ikke til at faa, undtagen Læderlapper: 1 Rmk. 40 Pd. 22.' J a n. Paul kom igaar Nat. Det er underligt at se ham i Uniform og hvilken Uniform!

24. J a n. Man veed intor, kun pet vord man med Bestemtherl, at Smør næsten ikke er til at faa, Mælk heller ikke, Brødrationer bliver nedsatte, Kød er vanskeligt at erholde, sarlig svine- og Kalvekød. Fisk ser vi ikke, Ris er færdigt. Bare Tyskland ogsaa snart var fardigt. Fader kom hjem med en markelig Nyhed. Landraaden har talt med Refshauge og foreslaaet ham til Kommune. forstander, der er nemlig en Post ledig. Refshauge har sagt til Landraaden, at han var dansk og ikke agtede at melde sig ud af de nationale Foreninger. Det behovedes hellor ikke, svarede denne, ligcledes har han sagt (det fortalte han selv): Jng satter, at Forhol- 
dene fører det med sig, at der bliver Afstemning i Nordslesvig, jeg stemmer dansk. Det maatte han have Lov til, svarede Landraaden. Skulde det virkelig være muligt, at vi faar en dansk Kommuneforstander her, og efterhaanden som der bliver Pladser ledige. I Dag Brev fra Cathrine, der har været syv Dage undervejs, og ogsaa idag Brev til Forældrene, der kun har været een Dag.

29. Jan. En Mand her i Byen, Nissen [Centralmejeriet], bekendt for sit gode Humør, sagde forleden: Tyskerne har ellers nok af store Ord og fedt Fläsk, nu har de endnu de store Ord og Marmelade.

3. F e b r. Stor Efterspargsel efter Smør i Forretningen, de vil betale langt over Højestpris. Man omgaar Loven. En Gaardmand havde fire Svin. Opkøberen og han bliver omtrent enige, der er jo Højestpris, men saa spørger Bonden: "Hvormeget vil du saa gi' min Kone?" og det ender med, at han maa give hende 300 Rmk., og først saa faar han Svinene. Saaledes i alle Forhold. 4. Febr. Afsendt Brev til Cathrine, vil nu altid notere Afsendelsen. 8. F e br. Masse Soldater er kommet bort, de samler alt, hvad de har, ved Vestfronten, saa jeg er bange.

10. F e b r. Den aarlige Generalforsamling i Exportforeningen med tilhørende Middag for en 100 Personer eller derover. Rose gav efter for Faders Opfordring og er gaat med, jeg synes det er rigtigt, da hun hører til Kontoret. 11. F e br. Rose havde moret sig ved Middagen igaar, havde haft den eneste Dame, on Mejeribestyrerinde [Frk. Bossen, Bjerndrup i Kliplev Sogn, død 1932] ved Siden af sig og nogle flinke danske [dvs. kongerigske] Mejerister i Nærheden. Fader blev meget hyldet, og det kan han jo godt lide, og var i udmærket Humør. Mange Taler, alle tilfredse. Damen viste sig at være baade original og intelligent, med Lidenskab for Musik. Hvad siger man om et saadant Menneskes Energi. Naar hun ikke kan faa Tid til at øve sig paa sin kære Violin, staar hun op om Morgenen Kl. 3. Kl. 5 skal hun begynde i sit Mejeri, og hun har sat igennem, at hun, hendes Lærer og en tredje spiller [Pleyels] Sonater engang om Ugen. Hun lærer sig selv at spille Fortepiano. Af en Indtægt paa $900 \mathrm{Rmk}$. med fri Bolig, Brændsel, Mælk og Smør kan hun lægge Penge op, saa hun kan købe baade Violin og Fortepiano og endda hjælpe sin Moder. 13. Febr. De nager. 14. Fe b r. I Lordags kom der Underretning til Christiansens, at den yngste af de Senner, der er med, Harald, er falden i Flandern. Stor Sorg. Han var et haabefuldt, stilfærdigt Menneske, sin Faders Yndling, kun 20 Aar. Ikke engang faar de at vide, hvor og hvorledes han er falden, hvor begravet, kun wden Heldentor fürs Vaterland", fra en Feldwebel.

16. Pakket til Soldaterne. 17. Febr. Pakket til Soldaterne. Alt bliver mere og mere knnpt. Ris kan ikke faas, Kalvekød heller ikke, Søbe 1 Rmk. Pd. Smor er rer intet at faa $\mu$ t købe $i$ hele 
Byen. Hvorledes mon det ser ud i store Byer. Egentlig burde Danskerne ikke hjælpe Tyskerne med at føde deres Børn og Fattige, nu begynder flere og flere at faa den Opfattelse, jeg havde strax. Hvorfor hjælpe at forhale Freden. Alt er jo saa tilspidset nu. Sult, Nød, Oprør - og Fordring om Fred. Gud give os den snart.

20. F e b r. Foraar i Luften. Stæren lod sine første forsagte Fløjtetoner høre, aa hvor man bliver glad og ser lysere paa Tingene. 2 3. F e b r. En Sorgens Dag. Kïrkeklokkerne ringer. Gud hjælpe de allierede til Sejr, det er min stadige Bøn. Det er jo ikke den enkelte jeg hader, men det er Princippet, Militarismen, saaledes som Preussen har opelsket den. 24. Fe b r. Atter Flagning. 25. F e b r. Stor Flagning [osv.]. Man bider Tænderne sammen og lider. 26. F e b r. En sørgelig Dag. Den første Del af Verduns Fæstning er stormet og taget. Nu opgiver jeg alt Haab. Flagning. 29. F e b r. Gudskelov endnu ingen Klokkeringning, eller Flagning, jeg er taknemlig for hver Dag, der gaar uden; det viser, at Franskmændene kan og gør Modstand. Rose kom hjem fra Vojens og fortalte, at der var kommet 230 Vognladninger Kreaturer fra Danmark i Dag og i Gaar. Thomsen har hørt to større tyske Gaardejere - Lorenzen [Revsø] var den ene - sidde og tale om Lyngen, der indføres her i utrolig Mængde: "Hätte nicht geglaubt, dass et soweit käme, dass wir die jütische Ileide aufessen sollten«.

1. Marts. Endnu ingen Sejrsmeldinger, ingen Klokkeringning, ingen Flagning, hver Dag er begyndt med Angst for disse Gentagelser. 4. M a r ts. Rose rejste i Dag med tre tyske Damer fra Landet. der sad og fortalte hinanden om Husholdningssager. Den ene fortalte, at de havde en hel Del russiske Fanger paa Gaarden til Arbejdet, men der var meget Besvær forbundet med at faa. Føde til dem; der var flere Ting, man kunde skrive om til Hamburg til "die Centralstelle» og faa udleveret, Bonner og nogle Gryn og andet, men det fordrede en Mængde skriftlige Erklæringer, og man maatte forpligte sig til kun at lade Fangerne faa det, man opnaaede at faa. "Die Soyabohnen sind aber gut, aber die andern sind ekelhaft, und einiges ist so, dass die Russen sich weigern es zu essen; wir mögen die Bohnen sehr gern". Saa sagde den anden Dame: "Aber Sie dürfen ja nicht davon essen?" "Ach", var Svaret, "wir essen getrost und geben was übrig ist zu den Russen«. Det blev optaget med Bifald af de andre, og Samtalen sluttede med, at en af dem sagde, vist med et Sideblik til Rose, der læste sin $»$ Politiken«: "In dieser grossen Zeit muss man stolz sein, ein Deutscher zu sein".

5. Marts. Gik Tur. Det hele blev fordærvet paa Hjemturen. Vi gik Simmerstedvej og saa Flag paa Kasernen. Gudskelov, det viste sig at være Flagning paa Grund af, at "die Möwe" var kom. met igennem Englændernes Blokade med hele sit store Bytte af Mennesker og en Million i Guldbarrer. 
8. Marts. En slem Dag. Man flager, og Løbesedler udgaar med Kant af Flagets Farver og Jærnkors i Hjørnerne. Desværre har de kastet Franskmændene [osv.]. Schmidt, Vojensgaard, var her til Middag. Han fortalte en Historie passeret i Flensborg fornylig. En hel Del Soldater skulde bort med Toget, og Obersten tilligemed flere Reserveofficerer, der havde uddannet Rekrutterne, havde givet Made paa Banegaarden. Kort for Toget skulde gaa, springer der en Soldat frem og henvender sig til Klyngen, raabende: "Ja, I kan sagtens, feige Kerle. I bliver hjemme, mens en Mand, der har Kone og Børn at ernære, sendes vak. I faar gode Gager, og vi faar nogle faa Penninge, hvoraf vi ingen kan sende, selv om de sulter nok saa haardt." Obersten rasende til hans Sidemand: "Grib ham, for ham bort, bind ham", men ingen af Compagniet rørte sig. Saa kom en Underofficer og slog ham med Kolben i Ansigtet, saa Blodet løb, saa bandt de ham og smed ham ind i Toget. De skulde til Fronten. Han bliver jo nok skudt, den ulykkelige. Man siger, der er Tusinder af den Slags i Fængslerne, nuest Socialister. - Kun Oxekød, ingen Gryn, Arter, Ris 1 Rmk. 40) Pd.

16. M a r t s. Gid jeg kunde rejse med $\mathrm{N}$. N., siger jeg det ene Øjeblik og i næste synes jeg dog, at saaledes som Forholdene er, er det bedst at blive sammen, de der horer sammen, og staa Last og Brast, man veed endnu ikke, hvad der kommer.

17. Marts. Stadig afgaar der Tog med Soldater til Fronten, 17-18 Aars Drenge gaar med, flere af vore gode Nordslesvigere er faldne ved Verdun. At de tyske Soldater ogsaa er kede deraf, viste et Kort, der ved en Fejltagelse blev afleveret her, adresseret til Fru Rosa Niels, skrevet paa mangelfuldt tysk: "Wenn doch blos das ganze Schitt ein Ende hätte", og "bri Verdun ist eine Schlachterei, wir müsses es ja nicht schreiben, aber Ihr könnt es in den Zeitung lesen".

20. Marts. Fader kom hjom fra Harmonien med følgende Historie, som [Johs.] Bramsen har fortalt: Pastor Wassner, Fjelstrup, talte fra Prædikestolen om den levende Satan og hvorledes han stod ved Siden af ethvert Menneske, og sagde: Naar en Soldat i Skyttegraven trykker sig for at storme, naar der bliver kommanderet, fordi han tænker paa sit Hjem og sine Kære, saa staar Satan bag ved ham, og til den Moder, der glader sig over, at hendes Søn er sluppet godt over Grænsen, siger jeg, Satan staar bag hende. Men jeg skal nok give ham det igen, sagde Fortælleren, vi leverer nemlig Kartofler herud til den frivillige Bespisning. hver efter sit "Reinertrag". Da nu Turen kom til Præsten, undskyldte han sig med, at han havde saa faa, han kunde ingen undvære, og blev derved, skønt Landraaden, hvem det blev forelagt, ikke billiger det. Nu vil jeg spørge ham, naar vi næste Gang ses, om han ikke tror, Satan staar bag ham, naar han nægter os Kartoflerne. [Præstegaarden stod til $1686 \mathrm{Rmk}$. Reinertrag. 11 Gaarde i Fjelstrup stod højere, mellem 3310, Niels Bramsens Gaard, og 1716.] 
21. Marts. Man flager. Hver Dag leveres der hele Batailler ved smørudsalgene. Folk faar deres Klæder flaaet i Trængselen.

29. Marts. Alt bliver nu indkaldt her og skal møde til Session. Er det mon nu Bunden de skraber? Rose har rejst med to Officerer i Toget. Den ene sagde: "Warum nehmen wir doch nicht Dänemark, warum warten wir, dass die Engländer es thun, ist doch ein Skandal.» Ligeledes blev der sagt af andre Officerer $i$ Kupeen ved Siden af: "Nicht viel Mannschaft heute, haben wir nicht mehr?". Den anden svarede: »Es war alles". Der afgik nemlig et Tog med Soldater den Dag. Der har været engelske Flyvere over Flyvehallen ved Tønder og paa Sild.

30. M a r ts. I Nat kom der en Soldat og ringede paa med Ordre til vor Indkvartering at rykke ud straks, de skulde til Grænsen. Vi blev alle alarmerede. tænkte os det værste, men da han kom hjem i Dag til Middag, fortalte han, det kun var en Øvelse. Det var altsaa en Proveballon.

1. A pril. Rose kom hjem og fortalte, at Schmidt paa Vojensgaard havde faaet Ordre til at holde sine Heste parate til at transportere Kanoner. 3. A p ri l. Byen er i Dag i Oprør og Uro, man taler om 30 engelske Flyvere ved Skærbæk. Soldaterne er febrilske, stiller med fuld Oppakning, Ordonnanser farer afsted, og Tog gaar til Grænsen med Landstormsmænd, flere Vogne med Spader er afgaaede, hos Fuglsang gaar der Vagt, man mener, der er Spranggranater og Ammunition opbevaret i Bryggeriuts store Lokaler. Man veed intet, men netop derfor er man saa ængstelig, og man læser vistnok en hel Del Lognehistorier. Men Uro er der, og noget er der ogsaa i Gære.

4. A pril. Byen er faldet til Ro.

5. A pril. Hr. Topfer og Søn til Aften. Overraskede mig selv, medens jeg sad ved Bordet og elskværdig parlerede tysk, at føle et intensivt Had til disse paatrangende af Vigtighed struttende Tyskere. Mærkværdigvis intet at opdage hos dem af Tvivl eller Modløshed: "Jetzt geht's ordentlich los bei Verdun, bald damit fertigu.

6. A p ri l. Rigskansleren har talt, altfor selvtillidsfuld og opfyldt af egen Storhed. Dog Fader var haabefuld og havde læst Talen anderledes og havde faaet Bluff ud af den, og mit Mod rejste sig atter lidt. - Boghandler Meyers Kone kom hjem fra Danmark, havde besøgt sine Forældre, de havde foræret hende et $20 \mathrm{Kr}$.s Guldstykke, det blev taget fra hende ved Gransen, og hun fik 22 Rmk. og noget i Stedet. 18. A pril. Paul kom med Nattoget. 26. April. Afsendt Smør til Gustav Johannsens Enke. 29. A pril. Desværre Klokkeringning. 30 . A pril. Der flages efter en større Maalestok. Landraaden imponerer med sex Flag, man kender dem ikke alle. Det er Kut-el-Amaras Overgivelse. 5. Maj. Man flager; kun Kronprinsens Fødselsdag. Offentliggørelse af den tyske Svarnote til Amerika. Fader mente, at de erkendte deres Svaghedstilstand, og det var Begyn- 
delsen til Fredsunderhandlinger, og at Amerika skulde være Mellemmand.

13. M a j. Havde bestilt 9 Pund Kød, fik kun 5, maa ikke sælge mere til een Husholdning. Det er svært at føre den. Det skal slaa til til hele Ugen. 17. M a j. Det bliver værre og værre med Levnedsmidler, heldigvis fik vi Fisk i Dag. Man stormer Butikkerne $i$ Byen.

20. M a j. Nu begynder Klokkerne at ringe, og de flager. Det er fortvivlende. Stor ostrigsk Sejr, Børnene har fri for Skole.

23. M a j. Hørte i Dag om en Soldat, der var hjemme paa Orlov og havde ligget i Skyttegravene i Frankrig; han fortalte, at der var stor Misfornøjelse blandt Soldaterne, et bayersk Regiment havde nagtet at gaa frem, Forplejningen yderst mangelfuld. De morede dem med at lave Carikaturer og anbringe dem iojnefaldende Steder. Det sidste var: England afbildet som en Mand ved Siden af en fed Gris, som han belaver sig til at skære et Stykke ud af; Frankrig, en Mand med Poser af Penge og en stor Vinflaske; Rusland med et vældigt Rugbrød, som han skærer et Stykke af; Preussen: Kejseren med en Marmeladekrukke vendt over Hovedet, saa Marmeladen render ned.

31. M a j. Man flager, Tyskerne har gjort store Fremskridt ved Verdun. Jeg gik paa Hjemvejen af min Tur ad Simmerstedvejen og saa pludselig Flagene, og blev saa bedrøvet, anede mig straks, at det var Franskmandene, der havde lidt Nederlag. Det Chok, man faar, naar man ser det hæslige Flag, vil jeg altid mindes med Skræk efter Krigen. Herregud, efter Krigen, det lyder saa ligetil og er dog saa langt borte.

3. Ju n i. Man flager [osv.]. Et stort Søslag med Sejr for Tyskerne og svære Tab for Englænderne. [Jyllandsslaget, hvor Tyskerne tilsidst flygtede og ikke senere vovede at optage noget Søslag]. 4. Ju ni. Flygte gjorde Tyskerne da, saasnart Englændernes større Stridskræfter kom til. 6. J u ni. En Ulykke kommer sjæIden alene. Medens vi sad ved Aftensbordet, ringede Telefonen, og Rose gik ud og kom tilbage meget altereret med den Meddelelse, at et stort Krigsskib med Lord Kitchener og hele hans Stab var gaaet under. Det var Svendsen, der telefonerede det. - Det har ikke varet muligt at faa Kød. Heldigvis har de fisket og faaet god Fangst, Fader en 8 Pd. Havørred. Det bliver knappere og knappere med alt.

9. J u n i. Paul er rejst i Dag til Magdeburg. 14. J u ni. Læste William Archers Svar til Brandes. Udmærket. Mine Tanker formet $i$ klare, overbevisende Sætninger. $18 . \mathrm{J}$ u n i. Maatte hente Kødet i al Hemmelighed i Gaar fra slagteren.

29. Ju ni. To Artikler i "Politiken« af G. Brandes, Gensvar til W. Archer, meget snusfornuftigt skrevne. Saasnart jeg havde læst de Linjer: For hvilket Ideal England kæmper, naar det prisgiver saa mange tyske Smaabørn som muligt til Hungersnøden, havde jeg 
nok. Tænkte mon Tyskerne paa de franske Smaabørn? Ak min Helt fra Ungdommen af, hvor er du blevet?

30 . Ju ni. Det er den sidste Dag, vi kunde faa Kød for Kødkortene, fik meget hemmelighedsfuldt en god Kalvekølle og en Lever.

1. J u li. Jeg klarede altsaa Formiddagen til Kl. 2, rexede en Del baade Steg og Fricandeau, stegte Lever og Karbonade, smæltede til, kogte Suppe og lavede Leverpostej, alt med $38^{\circ}$, bare det nu zaar, vilde ogsaa saa nødig det skulde fordærve, og det skal jo være vor Hjælp, naar vi ikke faar mere end de $31 / 2$ Pd. Kad om Ugen. - Frøken $\mathrm{X}$ fortalte, at der paatænktes at sende Feriebørn til Danmark; Folk havde derovre tilbudt at modtage herfra. Landraaden stillede sig meget venlig dertil. Jeg syntes, det var storartet, men da jeg saa opdagede, at det var Meningen ogsaa at sende tyske Børn (Frk. $\mathrm{X}$. fortalte om en Tyskers tre, der havde været hos hende og belt om at komme i Betragtning) blev jeg først saa forbavset, at jeg blev tavs; men saa lagde jeg heller ikke Fingrene imellem, spurgte hende, om de havde betænkt de Familiers Skuffelse, der offentlig havde tilbudt at tage sønderjydske Børn og saa fik tyske Legekammerater til deres gode danske Børn, som Forældrene vistnok havde fortalt om Tyskernes store Brutalitet netop overfor danske Børn hernede, og hvad de danske Børn har maattet døje i Skolen og i Livet og deres Forældre med. - Hun endte da med at sige, ja hun havde tænkt noget lignende, men det maatte jo dog være bleven undersøgt, inden de begyndte derpaa, og maaske kunde det være gavnligt for de tyske Børn at komme lidt til Danmark .... Sikke noget Nonsens. Jeg havde haft Lyst til at sige til hende, ogsaa du min Son Brutus, hvad kan man saa vente sig af andre. Ja det var nydeligt, jeg ærgrede mig.

6. Juli. Heldigvis har Myndighederne lagt Hindringer i Vejen for de Børn, der skulde sendes til Danmark. Frk. X. var nu meget glad derfor, det lod til, det rigtig var gaaet op for hende, at det vist var en gal Vej, de var inde paa. Hun fortalte Træk af preussisk Militarisme, som maa noteres. Paa Banegaarden var der kommet en hel Del Syge og medtagne Soldater. En gik saa daarligt og rystede saaledes, at han kun med Besvær kunde naa ind $i$ Byen. Folk havde Medlidenhed med ham og samlede sig paa hans Vej. Saa kom der en preussisk Hauptmann, og han snærrede: "Machen Sie keinen Skandal, sehen Sie, dass Sie fortkommen - til den ulykkelige Mand, der maatte tage Haanden til Huen og "Zum Befehle svare dette Asen, der skulde have haft et Slag i Ansigtet. Folk var meget indignerede. . 9. J u li. En Tunge 10 Rmk., en Lever 5 M. 80 (underhaanden), en halv Kalvekølle 34 Rmk. (omsaa underhaanden). 10. J u li. Travlt, rexet og lavet.

2.8. Juli. Det bliver vanskeligere og vanskeligere at faa Spisesedlen lavet. 29. Juli. En stor Sorg i Gaar, mit smukke 
Elmetræ lige udenfor mit Vindue blev hugget om, og hele Toppen af Akasietræet, det smukke Træ, der blomstrede, blev ogsaa fældet; nu staar det der som en Invalid, hæsligt at skue. Jeg led med Traet, jeg elsker dem jo som Medskabninger, det er jo min Fejl. At der skal mere Lys og Sol ind i Huset, forstaar jeg; men hvorfor saa brutalt, naar Træet staar i sin fagreste Pragt. Og mine glade Stære, der har boet der i saa mange Aar.

3. A ug. En Tunge fersk 11 Rmk., Svedsker 2 Rmk. Pd. Der er ingen Kaffe mere at faa. 5. A ug. Christine gik hjemmefra Kl. 6 imorges, stod i Rakke til 7 , kom hjem med 41/2 Pd. Oxekød, men ligesaameget skal hun hente i al Hemmelighed. Det er det, jeg siger, de rige kan altid faa, om end med Besvar, men de stakkels fattige, for dem er det forfardelige Tider.

8. A u g. Lise foreslog at tage med Toget til Hammelev og derfra gaa gennem Skov og Mark til Simmerstedvejen. Det gjorde vi, men det skulde vi ikke have gjort. Vi maatte vise vore Pas i Toget, blev os affordrede af en civilklædt Person med et ubehageligt Ansigt. Thomsen, der rejste i samme Kupé, sagde det var en hemmelig Politispion. Mit stirred han længe paa, spurgte, om jeg var preussisk Undersaat osv. og sagde tilsidst, at han beholdt Passet, det gjaldt ikke, jeg matte have et andet, henvende mig paa Politikontoret. Ved Udstigningen i Hammelev kom han atter hen, ledsaget af en Herre, der stillede sig helt fræk lige op ad os og undersøgte os, men ikke sagde noget, og paulagde mig atter at henvende mig paa Politikontoret, men var dog saa høflig at tilføje, at jeg havde ingen Skyld, der var kommet nye Bestemmelser for Udlandinge. Mit forste Besog i et Tog siden 1914, men Stemningen var forbi.

Et lille Eventyr med en russisk Krigsfange, hvem vi gav Cigaretter og Chokolade og snakkede lange med, mest pantomimisk, oplivede os atter. To Aar omtrent Krigsfange, været paa Lasaret, saa i Barakker, arbejdede nu paa en Gaard. Var ikke vant til at arbejcle, var "en stor Mand" hjemme, var generet af sine daarlige Klaeder; hed Nikolai, hans Kone Anna, hans ene lille Pige Alexandra. Han havde et rart fornøjeligt Ansigt med et vindende Smil og kunde le saa hjærteligt, ogsaa se helt fortvivlet ud, da han talte om to Aar og endnu ikke "Kaput». JIan lettede sit Hjarte ved at sige "tysk Canaille«. Vi fortalte naturligvis, vi var danske og enige med ham.

9. A ug. Har varet paa Raadhuset, intet Pas, maatte henvende mig til Generalkonsulatet i Hamburg, ingen kunde give mig Lov til at køre ud eller spasere uden for Censuren, inden jeg havde faaet Pashistorien i Orden, altsaa med andre Ord næsten Husarrest. Jeg besluttede saa at gaa til Landraaden, forklarede ham Sagen, hvorlænge jeg havde været her. at jeg havde haft Pas indtil igaar, spurgte ham, om han ikke kunde give mig Tilladelse til at kore ud uden Pas, thi det vilde jo tage Tid, inden jeg fik dot nye Pas, da 
de ikke paa Politistationen vilde give mig et. Han beklagede, at han ikke kunde give mig den Tilladelse, nu stod alt under Militærmyndighederne. Han spurgte meget om, hvad det var for en Herre, der havde taget Passet; jeg maatte forklare ham det hele igen, og han sagde, jeg burde have forlangt hans Navn og ligeledes at se hans Legitimation. Kort, han vilde nu undersøge Sagen, se om han kunde faa mit Pas tilbage eller et andet derefter, men han raadede mig til at skaffe et Pas fra København. IIan var i det hele meget elskværdig, men betonede stadig, at det vilde være forbundet med Fare, hvis jeg kørte ud eller tog med Toget uden Pas, og han havde ingen Myndighed. En Time efter at jeg var kommet hjem, ringede han mig op, han havde strax telefoneret til Flensborg, Herren, der havde affordret mig Passet, havde Ret dertil, og Passet var ikke gyldigt mere, men atter raadede han mig til at skaffe det fra København, endte med at beklage, at han ikke kunde hjælpe mig. Fader glad over, at det er kommet saaledes, og at jeg resolut gik til Landraaden. Nu faar vi se.

14. A u g. Rødspætter 1 Rmk. 60 Pd.; dyr Middag. Nu begynder det at knibe med Sukker.

15. A u g. H. P. Hanssen viste os skriftligt Forbud fra Censor, ikke at omtale de vestindiske Øers Salg og afholde sig fra alle Kommentarer desangaaende; han mente, Tyskland var ilde berørt af Salget til Amerika, begyndte at blive bange for, at det radikale Ministerium vilde blive styrtet. Ligeledes forbød Censor at skrive om de Uoverensstemmelser, der kommer tilorde nu om "Kriegsziele» i de forskellige Foreninger og Møder. Ian fortalte, at der bruges Sukker til Ammunitions-Frembringelse, derfor Knapheden, ligeledes blev Bomuldstøjer brugt dertil, der var i Hundredvis af Koner ifard med at klippe istykker og trævle op, og det medens saa mange mangler. Smør bliver ogsaa brugt paa Grund af Fedtmangel. Nu maa Mejerierne aflevere alt Smør og kun beregne sig selv. Men Fader siger, at Følgen bliver, at Bønderne tilbageholder Mælken og kærner. Christine, der har været hjemme i disse Dage, siger det samme.

19. A u g. En Tur ad Stokkerhoved-Moltrup Vej indtil den Gaard, hvor vi traf Nikolai sidst. IJavde forsynet os med Cigaretter, Chokolade, Tvebakker, men desværre kunde ikke faa ham i Tale, saa ham sammen med Manden og en Pige paa en Mark ifærd med at høste, var bange for at gaa derhen, vidste jo ikke, om Manden var dansk, det var en Skuffelse. Paul kom inat.

21. A u g. Modtaget mit Hjemstedsbevis, Pas kan ikke skaffes fra København, nu indgivet Ansøgning til det danske Konsulat om at faa Pas, medgivet Hjemstedsbeviset, min Skattebillet og mit Fotografi.

24. A ug. Paa Spadseretur ad Simmerstedvejen opdagede jeg pludselig, at Kasernen flagede, og jeg fik en Angst. Gudskelov, 
det var kun Undervandsbaaden "Deutschland«, der var kommet tilbage fra Amerika.

26. A u g. Svar paa Ansøgningen om Pas, der er flere Formaliteter at iagttage. Jeg gik strax paa Raadhuset og fik dem til at attestere, at jeg var identisk med Fotografiet og fik mit Signalement udfærdiget $o g$ sendte saa det hele idag tilbage.

27. A ug. "Jugendwehr" herfra samles med "Jugendwehr" fra Flensborg og Aabenraa; man siger her, at de bliver indøvede med det Formaal at skyde de civile, naar der bliver Oprør; de gamle Landstormsmænd vil ikke. I Kiel var det Politiet og "Jugendwehr", der skød, da der var Opror, Marinen og Soldaterne havde nægtet det. - Hørte i Dag, at det danske Selskab, der uforvarende i Bil var kommet over den tyske Grænse og blevet grebet, havde ved deres Hjemkomst sendt en Feldwebel, som havde været flink imod dem paa mange Maader, en Skinke, tænk en hel Skinke, hvad det betyder for en saadan Mand i disse Tider, men den var blevet ham frataget af de tyske Myndigheder.

29. A u g. Hurra. Rose kom hjem med den gode Nyhed, at Rumænien har erklæret Østrig Krig og Italien sendt Krigserklæring til Tyskland. Grenzpost er Gift og Galle imod Rlimænien, kalder det for wein Aasvogel«. Hvem er saa Aadslet? Der har den sagt en ordentlig Bêtise.

30. A u g. Faaet mit Pas.

2. Septbr. Sedandagen, men den fejres ikke iaar, det er forste Gang siden 1871. Stor Reklame for det femte Krigslaan, bruger alle Midler, om det saa er de stakkels Skolebørn. Hver skal medbringe 1 Rmk., saa er de ogsaa med at ofre "für das Vaterland". I Skolerne er der holdt en lille privat Sedanfest med "Ansprache« af en Lærer. I Augusta-Victoriasholen har han sagt: "Vore Fjender udspreder, at vi sulter og lider Nød, und wir haben doch in Hülle und Fülle und können mit beiden Hünden unseren Verbündeten geben«.

3. Se p t br. Vi var i Sølyst for første Gang iaar. Ingen Sukker til den slette Kaffe og Mælk istedetfor Fløde, man gik og tænkte paa svundne glade Tider.

7. Se ptbr. De flager desværre.

8. Septbr. : Nu kniber det ellers med Smør og Mælk. Heroppe er der endnu ingen Nød; dertil bidrager det kære Danmark en god Del; hvad her smugles ind, hvad her indføres, grænser til det utrolige. Det ene fyldte Jernbanetog efter det andet, siger $\mathrm{Fa}$ der, og de smaa Skuder, hvad de bringer fra danske smaa Havne, det skulde man undre sig over.

9. Septbr. Der kommer stadig Flyvere over Byen, man tror, det er engelske, de flyver saa højt oppe, der er kommet Kundgorelse i Avisen, hvorledes man skal forholde sig, hvis der bliver kastet Bomber. Nonsens, jeg tror ikke, Englınderne kaster Bomber paa en frellelig By, de er alt for meget Gentlemen dertil. 
10. Septbr. Den anden Koretur i Sommer. Stranden var herlig, drak alle Kaffe sammen hos den lille Fiskerfamilie [Halberg] med de elve Børn i Lysthuset, og Konen og Børnene gjorde alt saa pænt for os. Desværre var Konen i Sorg, hendes Mand var død af en Brandbyld, denne unge stærke Mand, der var Foregangsmand i saa meget og havde skabt sig saadan et pænt og godt Hjem og havde saamange Interesser. Konen er meget tiltalende og meget dygtig, og Børnene ualmindelig smukke, de sex er ude at tjæne, de fem hjemme. I det samme Lysthus har vi siddet en Sommerferie med Frøken Verrier [Datter af Professor Verrier] og været overstadig glade. Ak, hvor forandret.

11. Septbr. Kommet mange Soldater hertil, cler bygges en Flyverstation i Narheden af Kasernen, der er kommet en Afdeling Pionerer hertil. Ved Genner og Skærbæk anlægges der Skyttegrave. Det lader til, de er bange for Englænderne. 16 . Sept. Byen flager. 19. Se ptbr. Tyskerne herhjemme bliver bange, man siger, de pakker deres Sølvtøj og Kostbarheder og sender det bort. Der er atter kommet Soldater hertil, de graver Skyttegrave, særlig vesterude, og Pionererne har travlt ved Genner og Skœrbæk.

20. Septbr. Rose og Lise kom hjem med Fortællinger om, hvor nerves og urolig Byen er. Man venter Englenderne, og de allerfleste tyske Embedsmand har pakket og senult bort.

21. Septbr. Vi har faaet det nye Mel, det er skrækkcligt, begriber ikke, hvad det er blandet med.

23. Septbr. Rose rejste i Dag [i Kupé] med [en] Lieutcnant. Han talte en Del med en tysk, vistnok Domæneforpagter, og Kone, i Kupeen, og han udtalte blandt andet: "Finen entschiedenen Sieg kriegen wir nicht«. Og i Rusland mente han, var der intet at udrette, dertil var Landet for magtigt og Mnneskemængden for stor; "ja, havde vi den første Tid concentreret vort Angreb ved Kiew og naaet Odessa, saa - var der Haab». Fruen var fortvivlet over den Brødknaphed, der var, hun plejede at faa leveret $60 \mathrm{Brød}$ til Folkene og Husmændene, nu fik hun 15, hun maatte give dem Mælk og Grod, men hvad, naar Grynene slap op? I det hele taget var Stemningen trist.

30. Septbr. "I Dag er det sidste Gang", det Bud sendte Slagteren, at han ikke kan give os mere end de 3 Pund Kød, der tilkommer os. Alt slipper op for dem, kun ikke deres Frækhed og Anmasselse, ubegribeligt, at de ikke kan eller vil se deres Ruin.

7. Oktbr. Eneste Oplevelse var at se Arbejdernes glade Ansigter, da vi trakterede dem med en Kop varm Kaffe.

8. $0 \mathrm{ktbr}$. Der er en underlig Stemning over Folk i Byen, det er ligesom de venter noget, Tyskerne pakker sammen og sender bort, og Danskerne er bange for at blive sendt bort, hvis Fjendtlighederne med Danmark (med England) begynder.

9. Oktbr. H. P. Hanssen har medbragt foruroligende $\mathrm{Ny}$ - 
heder fra Berlin. Thomsens er taget ned til Familieraad, her er man ogsaa bange. Frk. Skjold havde ogsaa hort foruroligende Ting og var bange for, at I)anmark ikke kan holde sin Neutralitet. Tyskerne her forbereder dem paa alt. De Skyttegrave, der bliver anlagt vestpaa og ved Genner, bliver alle forsvarligt bygget med Cement og beskyttet af kolossale Masser af Pigtraade. Ved Ustrup og Vedsted er Skyttegravene allerede færdige.

11. Oktbr. Hvad mon Gud tanker om al den Odelæg gelse, det Slagteri, det Barbari? Mon ikke snart Ojeblikket er kommet for ham at standse det? Der var Kronik i Gaar af Karl Larsen. Han er dog en vammelig Karl. gid han vilde udvandre til det dejlige Tyskland med den storartede Organisation og Disciplin, saa var man da af med ham. At høre ham fortælle om de engelske Krigsfanger var vammeligt. Naturligvis har han ingen Forstaaelse af den ubandige Harme, der maa opfylde en engelsk Soldat, naar han prikkes med Naale og herses med af de Underofficerstyper, som er falles for dette beramte Kulturland Tyskland. Jeg kan godt forstaa, at det vist ikke var nogen sarlig fin Hilsen eller respektfuldt Blik han tik.

16. Ok tbr. Fader i Aabenraa, Hanssen har sammenkaldt en Kreds af Mænd for at sætte dem ind i Situationen. - En Skinke, fersk, 33 Pund, er blevet betalt med 100 Rmk., en Gaas med 80 .

17. Oktbr. H. P. Hanssen gav en saadan Beretning om den øjeblikkelige Situation, at Fader kom lidt porplex hjem. Han mente, at alle de cementerede Skyttegrave, Banen, alle de Kanoner, Anımunition, Soldater, var sendt herop med den Tanke, at det vilde bryde ind her, de venter Englienderne og Danmark som dets allierede, og med vanlig Forudseenherd bliver saa alt det gjort $i$ Tide. Hvis det sker, vil der 24 Timer i Forvejen af Hanssen blive udsendt Avis. Han mente, alle vi vilde blive transporterede sydpaa. Men en stor Gevinst er det dog at faa det at vide 24 Timer i Forvejen. Stakkels Lise, som er saa nervos, sov ikke for at spekulere over, hvad hun skulde tage med. Jeg tror ikke paa det, de har alle nok at gøre, saa maa det blive tilsidst, nar Tyskland ikke paa anden Maade kun bringes i $K n æ$, og Danmark tænker kun paa at hytte sit Skind og tjæne Penge og - more sig.

18. O $\mathrm{ktbr}$. I Dag har Fader faact at vide, at Hestene vil blive tagne, det or en Sorg.

21. Oktbr. Fn ung Mand, der er ansat i Forretningen i Vojens, var her i Dag som Soldat. Han har veret med ved Verdun; hvad han fortalte derom, var skrækkeligt, ogsaa om, hvad den stakkels civile Befolkning i de occuperede Egne maa lide. Han ligger nu bagved Fronten i roligere Egne. Han fortalte om en velstaaende Købmand, som blev tvunget til at arbejde for Tysklands Befæstninger, fik 1 Rmk. 20 om Dagen, hans Hander, uvante til legemligt Arbejde, hang i Laser, han var pjaltet, luset og saa undererneret, 
at han ikke kunde vente, til Kartoflerne blev kogte, og han havde ejet helc det Terran, hvorpaa en hel Bataillon var anbragt, og det var hans Marker, som Soldaterne plyndrede, hans Frugttrace, alt var herøvet ham og han maatte tigge for at leve, tigge af Bødlerne. Han fortalte alt det saa selvfolgeligt uden at tronke dybere. Han er jo ogsaa saa ung.

25. Oktbr. Fader siger: Enden er ikke endda. Lad os se først. 26. Ok t b r. Hvor er det tomt, naar man kommer i stalden. Vore stakkels Dyr, de er førte sydpaa, dot har vi faaet at vide. Og de, som var godt vante, maa nu pludselig daje ondt, lide. Aa, hror er det oprorende, at de saadan uden videre kan tage Folks Ejendom.

27. Oktbr. Fru Thomsen fortalte gruopvipkende Ting fra Fangelejrene. Det er sandt, at naar Fangen ikke absolut vil gøre alt, hvad Opsynet befaler, bliver de bundne til en Prl, en frygtelig Tortur. Skammen over en saadan Behandling kommer til at hvile paa dem, der udøver den. Hvor maa de stakkels Fanger ikke vare opfylite af Had og Havn, og hvad har Tyskerne ikke samlet sammen, som de ma bode for og svare til - efter Krigen. Man bliver helt uhyggelig til Mode, naar man laser (irenzpost's hoverende Opramsen af alt, hvad der er ollelagt, man kommer til at tanke paa Dja"vle, der fryder sig over alt det onde, de gor.

30 . O k tbr. Der gaar vilue Rygter om, at Tyskerne har i Sinde at fouragere i Jylland; man siger, der er kommet 30,010 Mand herop paa Strakningen Vedsted Skirbak; der arbejdes paa Kraft. Der var en Underofficer i Gaar og forlangte at blive indkvarteret med Forplejning. Vi nægtede det, nu faar vi se, hvad det fører til. Vi har jo intet tilovers, men lige til Husbehov. Sukker intet, Gryn af forskellig slags kan vi heller ikke faa, smor er dot ogsaa knapt mod. Køal lige til Husbehov.

31. Ok tbr. En Oplevelse har man da: at lase Rigsdagsforhandlingerne. Ciudbevares hvor de skendes og hvor Ophidselsen er stor i Debatten om "Sichutzhaft«. Naar Krybben or tom, bides Hestene. Dittmann, Socialist, har talt uden Umsvob og blottede hele Misèren, Helferich blev meget lille tilsidst. Elsasseren I)r. Hausz og Scheillemann var ogsaa sarrlig gode. Men Tyskere ar Tyskere. Selv om de indser, at de or par gal Vej, at det hele er desperat, behoves der kun "Vaterland, das grosse, Kaiser, Aushalten, Durchhalten" - og saa brøler de op.

8. Novbr. Vi har faaten Sark lavre fra Vojens for at male, men pyt, man maa aflevere IIavren, og hvad faar man i Stedet, saa og saa mange Havregryn fra Lübeck, hvor de naturligvis er godt blandede og forfalskede. Alt er forfalsket og umaadelig dyrt. En Gaas blev købt $i$ Gaar af en af Faders Bekendte: $36 \mathrm{Rmk}$., et Par uldne Strømper koster her 4 Rmk. 50.

12. Novbr. Fader er bange, Thomsen bliver taget.

16. Novbr. Der or ingen Gryn at faa af nogen Slags. Det bliver varre og varre med alt. Smaa Torsk til on Midilag 6 Rmk. 
17. Novbr. Poul er kommet, 14 Dage Orlov, Rose glacl. 21. Novbr. Nu er der ingen Kaffesurrogater at faa mere, og med Kølet er det knapt tilmaalt denne Uge. 22 . Novbr. "Bet- und Busstag“ i Ordets virkelige Forstand. 23. Novbr. I Dag dukker for første Gang Civiltarnestepligt op i de tyske Blade. Det bliver inclgribende Forandringer baade i Handelsverdenen og for Arbejderne. 25. Novbr. Horte i Dng, at tyske Soldater i Uniform uden videre gaar over Grænsen nasten til Kolding for at fouragere, og det uhindret. 29. Novbr. Mis har taget sine Unger og ført dem over i Laden. Det er vistnok, fordi der var saa mange Haandværkere i Gaar ng usikkrrt. Men hrorledes den har baaret sig ad dermed, er ell Gaade.

1. De cbr. Det er en skarp, bidende, giftig Kronik om Ruslanils og Englands Forhold til Persien, Brandes offentliggor i Politiken. Man forbavses over hans eminente Viden, hans Hukommelss, hans skarpe Logik, men man er dog reserveret, man tror ikke rigtig nu; han har selv Skyld, han har ikke vist sig under Krigen som den Ridiler sans peur et sans reproche, som da han skrev Don Quichotr. denne lille Skitse af sig selv.

2. Decbr. I Byen alt ode og forladt og morkt. Stakkels Mennesker. Hver har nok i sit. 4. Decbr. Opdagede pludselig, at man flager. Det giver et Chok i en-, tænkte paa mine stakkels Franskmænd ved Somme. Jeg maatte ind til Byen for at faa noget at vide, og i Mørke. Regn og Rusk traskede jeg afsted helt ned i Byen, men intet Steds var der opslaaet noget. Saa kom jeg $\mathbf{i}$ Tanke om min Cigarenke, jeg derind, købte en Kasse Cigarer - uden Penge -. til Soldaterne og fik saa at vide, hvad jeg vilde. Naturligvis var det bedrøveligt, men det kunde være værre, Det var et stort Slag, de havde vundet $i$ Nærheden af Bukarest. Kejseren havde befalet "Sicgesgeläute«, og Bornene fik fri fra Skole.

5. De c br. Vi modte tre store Læs Roer, der karte ind hos Fuglsang for at torres og saa anvendes til Brod. Intet at faa af Gryn nogrtsterls, vi maa takke for vore Prøvepakker, de hjælper svært. Ost: intet at faa, Chokolade: intet, og kan man opdrive en Tavle, knster den det firdobbelte. 6. D e c br. Den civile Tjænestepligt altsan vedtaget. Gud naade de stakkels Arbejdere og de Kvinder, der tages til Ammunitionsfabrikker; det bliver en haard Vinter. Men Leverandorerne og Fabrikanterne skovler Penge ind. Hvad tjener ikke Krupp? Socialisterne har spillet deres Kort skidt. 7. D e c br. Bukarest taget. Ordineret: "Flaggen, Siegesgeläute, Salut".

9. D e c br. Har læst Maeterlincks Raab til de neutrale om at hjælpe de værgeløse Bclgiere og udfri dem af det nedværdigende Slaveri, Tyskland nu bereder dem. Atter er Tusinder forte bort fra deres Land til Tyskland for at arbejde i Ammunitionsfabrikkerne, hjælpe Fjenden til at adelægge deres Land endnu mere; det kan kun en Nation som den tyske gøre; de, der taler højest om deres Moral. 
Fader kom hjem og fortalte, at i Kloppenborgs Egn var der organiseret hele Smuglerbander, der førte en Masse over Grænsen. Købmændene tjænte hele Formuer, de kunde næsten forlange, hvad de vilde; den ene Agent overbød den anden. Hele Nordslesvig er oversvømmet af Agenter, mest fra Berlin, de køber Rub og Stub. Der er kommet 1000 Mand her til Byen i Dag, skal indkvarteres i tre Uger. Vi har faaet en Lieutenant, men Fader har faaet ham anbragt paa Jærnbanehotellet.

1 2. D $\mathrm{D} \mathrm{c} \mathrm{b}$. Ganske mærkværdigt: Tyskland har erklæret sig villig til Fredsunderhandlinger, Kejseren forkynder det $i$ en bombastisk Tale for sine Soldater tillands og tilvands. Jeg blev saa glad, har intet kunnet sanse hele Dagen, skulde det mon nu være Begyndelsen til Freden. Eller er det et Skaktræk fra Tysklands Side. Men jeg kan da ikke tro, de vil spille Komedie for dem selv. Eller er det for Folket? 13. Decbr. Rigskanslerens Tale er ikke skikket til at opnaa Fred, han slaar stadigt paa Sværdet og lyver nederdrægtigt, naar der er Tale om Ernæringsspørgsmaalet. Saa svandt den Drøm.

15. Decbr. Haft travlt med Pakker til Soldaterne. 16. D e c br. Travlt med Julepakker til Soldaterne.

19. D e c br. Det var med et straalende Smil, at [Snedker] Ratenburg sagde: "Det har nok været en stor Sejr for Franskmændene«. Man mærker straks Samhørigheden i saadan en lille Ytring.

30. De c br. Det bliver værre og værre med Næringsmidlerne, med Mælk og Kartofler er det on ren Misère, nu begynder ogsaa Kulkortene, men det er med dem som med Sukkeret, Kortene har de, men hverken Kul eller Sukker faar de, kun Løfte om næste Uge.

(Sluttes). 